\title{
Impact of alternative regional trade arrangements on the Ethiopian economy
}

\author{
Habtamu Shiferaw Amogne* (D) and Taiji Hagiwara
}

\author{
*Correspondence: \\ habtamushiferaw2018@gmail.com \\ Graduate School of Economics, \\ Kobe University, Address: 2-1 \\ Rokkodai, P.O.Box 657-8501, Nada, \\ Kobe, Japan
}

\begin{abstract}
The Common Market for Eastern and Southern Africa (COMESA) is a Free Trade Area (FTA) regional trade agreement in Africa. Currently, Ethiopia is negotiating to join COMESA FTA. This study assesses the impact of three regional trade arrangements, COMESA FTA, customs unions, and the European Partnership Agreement (EPA) on the economy of Ethiopia. The analysis is based on a static Global Trade Analysis Project (GTAP) model, version 9 database. Unlike previous studies, the customs union scenarios are designed at the detailed Harmonized System (HS) level. COMESA FTA (scenario 1) with standard GTAP model results in a welfare loss for Ethiopia due to negative terms of trade and investment-saving effect, but with unemployment closure (scenario 2); Ethiopia enjoys a welfare gain mainly due to endowment effect. In scenario 3 (COMESA customs union) and scenario 4 (European Partnership Agreement), Ethiopia loses due to negative terms of trade and investment-saving effect. There is a large increase in demand for unskilled labor force in Ethiopia by around US\$23 million, US\$112 million, and US\$43 million for scenario 2, 3, and 4 respectively. Moreover, there is a positive output effect for oilseeds, leather, and basic metals across all scenarios. The world, as a whole, enjoys welfare gains with COMESA FTA (scenario 1 and 2). However, with scenario 3 and 4, there is an overall welfare loss. There is no strong reason for Ethiopia to move to the customs union, and the EPA in the short run. Therefore, a transition period is necessary, but it is recommended for Ethiopia to join COMESA FTA.
\end{abstract}

Keywords: Free trade area, Customs union, EPA, COMESA, Ethiopia, GTAP

JEL classifications: F11, F13, F15

\section{Introduction}

Regional trade agreements (RTA) have proliferated around the world since the establishment of GATT/ WTO, and now almost all the members of the world trade organization are member of at least one RTA. In terms of quantity, there is an increasing trend of RTA formation, and currently the cumulative notification of RTA in force reaches 471 while the number of physical RTA in force are 293. ${ }^{1}$ Fiorentino et al. (2009) explain the current wave of RTA in four different but related ways. First, there is an increase in North-South RTA, a gradual replacement of the long established non-reciprocal system of preference,

\footnotetext{
${ }^{1}$ For a complete list of RTAs notified and in force to the GATT/WTO see https://www.wto.org/english/tratop_e/regio n_e/region_e.htm.

(c) The Author(s) 2021. This article is licensed under a Creative Commons Attribution 4.0 International License, which permits use, sharing, adaptation, distribution and reproduction in any medium or format, as long as you give appropriate credit to the original author(s) and the source, provide a link to the Creative Commons licence, and indicate if changes were made. The images or other third party material in this article are included in the article's Creative Commons licence, unless indicated otherwise in a credit line to the material. If material is not included in the article's Creative Commons licence and your intended use is not permitted by statutory regulation or exceeds the permitted use, you will need to obtain permission directly from the copyright holder. To view a copy of this licence, visit http://creativeco mmons.org/licenses/by/4.0/.
} 
and an increasing number of south-south RTA. Second, there are an increasing number of cross-regional trade agreements. Third, there is a decreasing propensity for plurilateral RTA and a net increase in the number of bilateral RTA. Fourth, Free Trade Areas (FTA) is more attractive to countries that are committed to comprehensive trade liberalization compared to customs union and partial scope agreements.

Eight building blocks Regional Economic Communities (REC) are recognized by African Union to facilitate the regional integration agenda in Africa and boost intra-Africa trade. Common Market for Eastern and Southern Africa (COMESA) is one of those regional economic integrations selected by the African Union for the formation of Continental Free Trade Area (CFTA). Out of 19 COMESA member countries, Ethiopia, Eritrea, and Swaziland are negotiating to join COMESA FTA.

Economic integration includes various forms of integration such as a free trade area, customs union, common market, economic union, and total economic integration (Balassa 2013). Several theoretical explanations are given for the formation and proliferation of RTAs in the form of FTA and customs union. The probability of FTA formation is higher when the partners are closer geographically, more distant from the rest of the world, larger and more similar in economic size, and further apart regarding per capita incomes (Baier and Bergstrand 2004). However, countries with similar economic structure, but different FTA structure, may have different propensities to form new FTAs. Hence, the existing relationship between FTA negotiating countries and third countries also force the two countries to form FTA (Chen and Joshi 2010). A more recent study further argues that the signing or deepening of one FTA can induce excluded nations to sign new FTA. Thus, FTAs are contagious (Baldwin and Jaimovich 2012).

Empirical studies show that FTA increases member countries' bilateral trade through their trade creation effect when a member country's domestic production of an item falls and is displaced by low-cost production by a partner country (Baier and Bergstrand 2007). However, there is also a trade diversion effect on non-participating countries resulting from the issue of rules of origin. According to Krueger (1997), FTA, which maintains each country's individual external trade barriers, but removes barriers on trade between the member countries result in three related consequences; first, there is a possibility for 'trade deflection'. Second, Rules of Origins (RoOs) can in effect 'export protection' from one country to another. Third, the fact that protection rates are different implies that producers in partner countries cannot be facing common prices of tradable or of non-tradable that use significant quantities of tradable as inputs. Therefore, comparing FTAs and customs union based on welfare: an FTA can not lead to any more trade creation than can a customs union and, when RoOs export any protection, an FTA leads to more trade diversion than does a customs union. ${ }^{2}$ On the other hand, whenever there is trade creation under customs union, it seems evident that it will also occur under an FTA, and there is no mechanism by which there might be more under an FTA. Nevertheless, countries might have tariff structures such that averaging of tariff rates resulted in higher effective protection levels under customs union than under an FTA, and that this could result in greater trade diversion under a customs union than

\footnotetext{
2 The main assumptions is that the customs union adopts a common tariff for each commodity at a level somewhere between that prevailing pre-union in the higher-tariff country and the lower-tariff country, that the common external tariff be such that effective rates of protection are not increased under customs union.
} 
under an FTA. Although there is more welfare gain associated with customs union, some countries may not agree to join customs union in the first place. However, the trade-diversion effects of customs union formation can induce those nations that were previously against membership to join and an economic incentive to join increases with the customs union size (domino effect of custom unions) (Baldwin 1993).

Several studies on Africa reveal that regional economic integrations are not sufficient to increase intra-Africa trade, but there is strong evidence of a trade creation effect (Mevel and Karingi 2012; Mureverwi 2016; and Ngepah and Udeagha 2018). There is overall welfare gain from trade liberalization in most African REC, but the country-level welfare effect is unbalanced, and some countries experience welfare loss (Sawkut and Boopen 2010). In general, the welfare effects of FTA and customs union depend on the pre-existing trade share between negotiating countries; the larger the share is, the larger the net trade creation and the smaller the trade diversion effect. Likewise, when preexisting tariffs are very high (so that there is little trade to divert) or very low (so that the costs of trade diversion are low), welfare is more likely to improve with the formation of customs union. Besides, the size of the tariff reduction also determines the welfare effect from FTAs and customs union.

Themain purpose of this study is to analyze the impact of tariff reduction under three regional trade arrangements on the economy of Ethiopia. First, Ethiopia is a member of COMESA, but not a signatory of the free trade area. Therefore, we evaluate the macroeconomic and welfare impact of the free trade area between Ethiopia and COMESA member countries. Second, COMESA member countries agreed to levy a Common External Tariff (CET) on non-member countries and form a customs union. Hence, we extend our analysis to the case where Ethiopia joins the COMESA customs unions in an operational free trade area. Third, there are ongoing trade negotiations between African countries and the European Union (EU), European Partnership Agreement (EPA), to remove the tariffs imposed by African countries on EU products. We use static Global Trade Analysis Project (GTAP), Computable General Equilibrium (CGE) model, version 9 database to achieve the three objectives.

Analysis of deep regional integration between COMESA and Ethiopia, is vital for the following reasons; first, Ethiopia is the fourth largest economy in Sub-Saharan Africa (SSA), and the country has an abundant cheap labor force and a market of over 100 million people. Second, the Ethiopian economy is highly protected in Africa by a substantial tariff rate, and has very low trade with COMESA countries. Third, from a geopolitical perspective, Ethiopia has a significant place in the horn of Africa.

This study contributes to the existing literature in the following ways. First, despite several studies on COMESA, there has been little analysis of different regional trade arrangements. In this study, an important distinction is made between free trade areas, customs union, and the European Partnership Agreement. Second, unlike previous studies, the COMESA customs union scenarios are designed at the detailed HS6 level. Third, to account for unemployment in Ethiopia, and other COMESA countries, the model assumes endogenous unskilled labor supply, and exogenous wage. However, for scenario1, we provide a result with standard model closure. Further, 140 regions and 57 sectors are aggregated into 18 regions and 18 sectors (Appendices I and II). 
The empirical literature on different regional trade agreements in Africa is reviewed in Sect. 2. Then, a brief description of COMESA member countries' economies is analyzed using social and macroeconomic variables in Sect. 3. After that, the protection patterns of COMESA and Ethiopia with other regions are explained. We explain the model database and simulations in Sect. 4. Section 5 discusses the macroeconomic and welfare results under different scenarios, and Sect. 6 concludes the paper.

\section{Literature review}

The proliferation of regional trade blocks has attracted interest among academics and policy-makers in Africa. Several studies have been done to analyze the welfare and macroeconomic impact of different regional trade arrangements in terms of free trade areas, customs union or preferential arrangements in Africa, particularly in the COMESA. However, the scenarios of trade liberalization policies, the period of assessment and the structures of the model employed vary among these studies. Moreover, most studies use partial equilibrium models, such as the gravity model, which focus mainly on the trade effect of trade liberalization policies, while others use general equilibrium models to analyze both welfare and the trade effect. The use of general equilibrium models over partial equilibrium ones has the advantage of capturing the complex relationship between and within sectors as a result of trade liberalization measures. In this section, we focus on studies that use both partial and general equilibrium models.

Conroy (2013) uses Gravity model and shows that there is a large trade creation effect of FTAs for two regional trade arrangements, namely, COMESA and Mercado Común del Sur (MERCOSUR). The FTAs increase intra-COMESA and intra-MERCOSUR trade with little trade diversion from non-MERCOSUR member countries. These findings, further stresses that the trade creation effect for COMESA regions are concentrated in the sectors where COMESA FTA member countries have varying comparative advantages. Similarly, Musila (2005) studies the impact of FTA formation across three regional trade agreements in Africa, namely, COMESA, Economic Community of West African States (ECOWAS), and Economic Community of Central African States (ECCAS). The analysis shows that the trade creation effect of forming an FTA differs across the three RTAs depending on the depth of trade liberalization reforms undertaken. There is more of a trade creation effect for ECOWAS and COMESA, with net welfare gains, while there is no trade creation impact for ECCAS. Moreover, Karamuriro (2015) finds that the formation of COMESA trading block has increased intra-COMESA export, but deepening regional economic integration through investment in transportation cost or reduction of trade cost would have more impact on the economies of COMESA.

A CGE model-based study on grand regional integration in Eastern and Southern Africa indicates that, with trade liberalization, new trade is created and the welfare of society is improved through access to cheap products. However, the gain differs across participating countries depending on their initial protection structure, existing trade relationship with other member countries, and the level of non-tariff measures imposed by each country. A study on the Tripartite Free Trade Area (TFTA) indicates that the Southern African Development Community (SADC) region, which has a less protected and more diversified economy, experienced large benefits from the TFTA followed by the East African Community (EAC) and COMESA (Karingi 2009). Similarly, 
Makochekanwa (2014), using a World Integrated Trade Solution (WITS)-SMART model, estimated that, with the TFTA, US $\$ 2$ billion in trade will be created, and US $\$ 454$ million in trade will be diverted, resulting in net trade of more than $\$ 1$ billion. The most trade will be created by the SADC region, followed by COMESA and the EAC, while there is more trade diversion impact from the COMESA region.

Few studies use the GTAP CGE model to analyze the impact of trade liberalization policies in the form of free trade areas and customs union among COMESA member countries. A study by Karingi et al. (2002) analyzed the impact of COMESA free trade areas and customs union on the economies of member countries. The study shows that free trade areas give good outcomes, but customs union must be preferred, and the member countries benefit from customs union in terms of real incomes and a reduction in poverty. These results emphasize that the impact of customs union depends on whether the average existing tariff rate is higher or lower than the CET rate; the larger the average existing tariff rate, the higher is the gain from forming a customs union. Hence, customs union create an opportunity for non-member countries to export to the COMESA region. Moreover, the sectoral result shows that to benefit more from customs union, the transition period between free trade areas and customs unions should be larger. A similar study on COMESA finds a positive welfare and trade gain from customs union, but the best impact in terms of real GDP and welfare occurs when COMESA customs unions are formed after the COMESA free trade area is operational among all member countries (Sawkut and Boopen 2010). In contrast, a study using the Modeling International Relationships in Applied General Equilibrium (MERAGE) CGE model finds that customs union will not be beneficial to a majority of the member countries, and some countries experience tariff revenue and real income loss (Nzuma et al. 2009). This is due to an increase in protection by some countries.

Traditional tariff barriers have been reducing across time for developing countries due to the proliferation of regional trade agreements and the unilateral preferential trade agreements with developed countries, which allow them free access to developed countries' markets. However, international trade still faces large trade costs and non-tariff measures that reduce the benefit of trading across the borders. A study on the eastern and southern part of Africa divides trade costs into three components: trade facilitation, non-tariff barriers, and costs of business services. The results indicate that deep integration among the EAC, COMESA and SADC regions results in significant gains in trade and welfare, but the estimated gains vary across countries and regions. Further, trade facilitation tends to increase incomes of the poor and reduce inequality, while service liberalization increases inequality (Balistreri et.al. 2016). Similarly, another study on EPA negotiation finds that facilitating trade by reducing both export and import time delays would have a positive impact on trade flow (Persson 2008).

The negotiations between African Caribbean and Pacific (ACP) countries and the EU continue to attract the attention of African policy makers as the EU has decided to remove their unilateral trade preference for countries that have not signed or ratified the EPA. Several studies indicate that the majority of ACP countries experience overall welfare gains but also budgetary difficulties as a result of the loss of trade tax revenue under the EPA and associated adjustment costs related to tax policy and administration reform (Bilal and Roza 2007; Karingi et al. 2006). Moreover, the EPA also has a severe impact 
on deepening regional economic integration in Africa, as some trade would be diverted from the region toward the EU. Therefore, African countries should combine both regional integration agendas and the EPA (Hamouda et al. 2006; Karingi et al. 2006). A similar study on the SSA finds that some SSA countries, such as Botswana, Cameroon, Mozambique, and Namibia, would significantly benefit from the interim EPA agreements, while the trade effects for Côte d'Ivoire, Ghana, Kenya, Tanzania, and Uganda would be close to zero (Vollmer et al. 2009).

The empirical literature explained above signifies the following key points. First, COMESA FTA and COMESA customs union improve the aggregate welfare of COMESA, as well as the world, while some individual countries experience welfare losses. The trade creation effect of both FTA and customs union outweighs the trade diversion effect, but depending on the initial trade share and protection level, some countries may experience a greater trade diversion effect. Third, there is substantial revenue loss associated with free trade areas, customs union, and the EPA, as import tariffs are a main source of revenue for most African economies.

Several studies analyzed the effects of free trade, customs union and the EPA on the economies of Eastern and Southern parts of Africa but, to the best of our knowledge, no previous study has looked at this issue in the context of Ethiopia's relations with COMESA countries. Most importantly, this analysis focuses on comparing three regional trade arrangements using tariff reduction as a liberalization policy, namely, COMESA free trade areas, COMESA customs unions, and the EPA for Ethiopia. Our tariff scenarios for customs union are prepared at the detail HS6 level, rather than at the aggregated level.

\section{The COMESA economy: a descriptive exposure}

\subsection{Economic character of COMESA}

Demographic differences across countries influence the level and composition of trade, both through their impact on comparative advantages, and on patterns of demand. As shown in Table 1, Ethiopia, Egypt, and D.R. Congo are the most populated countries, while Seychelles, Djibouti, and Comoros have small populations.

Table 1 further reports the relative size of economies of COMESA member countries measured by Gross Domestic Product (GDP); Egypt, Sudan, Ethiopia, and Kenya are the four largest economies among COMESA member countries. In addition, the GDP per capita of COMESA member countries varies widely and ranges from US\$ 712 in D.R. Congo to US\$ 25,172 in Seychelles. The large GDP per capita in Seychelles, Mauritius, and Libya shows the high growth performance in the economies of these countries. Table 1, column 4, reports the trade-to-GDP-ratio measured by the sum of exports and imports divided by GDP. This indicator measures a country's 'openness' or 'integration' in the world economy. Trade constitutes 181\% of Seychellois's GDP, 114\% of Mauritius's GDP, and $147 \%$ of Libya's GDP. In contrast, Sudan, Egypt, Ethiopia, Burundi, Rwanda, and Uganda have a relatively small trade-to-GDP ratio-below 50\%-suggesting plenty of room to increase openness.

The breakdown of value added by activity indicates a considerable variation of economic structure across COMESA member countries over the period of 2010-2014. Agriculture is a dominant sector, with agriculture's value added constituting more 
Table 1 Economic character of COMESA regions. Source: World Development Indicators

\begin{tabular}{|c|c|c|c|c|c|c|c|}
\hline \multirow[t]{3}{*}{ Country $^{a}$} & \multirow{3}{*}{$\begin{array}{l}\text { Population } \\
\text { (million, 2014) } \\
\\
(1)\end{array}$} & \multirow{3}{*}{$\begin{array}{l}\text { GDP (US\$ } \\
\text { million, 2014) } \\
\\
\text { (1) }\end{array}$} & \multirow{3}{*}{$\begin{array}{l}\text { GDP per capita } \\
\text { (in US\$, 2014) } \\
\text { (3) }\end{array}$} & \multirow{3}{*}{$\begin{array}{l}\text { Trade, (as \% } \\
\text { of GDP) (2014) } \\
\text { (4) }\end{array}$} & \multicolumn{3}{|c|}{$\begin{array}{l}\text { Average Value } \\
\text { added (As \% of GDP) } \\
\text { (2010-2014) }\end{array}$} \\
\hline & & & & & \multirow{2}{*}{$\begin{array}{l}\text { Agri } \\
(5)\end{array}$} & \multirow{2}{*}{$\begin{array}{l}\text { Ind } \\
\text { (6) }\end{array}$} & \multirow{2}{*}{$\begin{array}{l}\text { Svces } \\
\text { (7) }\end{array}$} \\
\hline & & & & & & & \\
\hline Burundi & 10.80 & 7944.82 & 734.48 & 41.31 & 40.09 & 17.31 & 42.60 \\
\hline Comoros & 0.80 & 1049.93 & 1363.56 & 79.92 & 38.24 & 11.57 & 50.19 \\
\hline D.R.Congo & 74.90 & $53,238.84$ & 711.52 & 80.06 & 22.76 & 33.71 & 43.53 \\
\hline Djibouti & 0.90 & 2733.70 & 3120.04 & N.A & N.A & N.A & N.A \\
\hline Egypt & 89.60 & $900,147.80$ & $10,045.78$ & 37.41 & 12.34 & 38.37 & 49.29 \\
\hline Eritrea & 5.10 & N.A & N.A & N.A & N.A & N.A & N.A \\
\hline Ethiopia & 97.00 & $138,728.89$ & 1430.8 & 40.74 & 44.84 & 11.50 & 43.66 \\
\hline Kenya & 44.90 & $126,449.16$ & 2818.26 & 51.12 & 29.18 & 20.36 & 50.46 \\
\hline Libya & 6.30 & $93,133.61$ & $14,879.99$ & 147.58 & N.A & N.A & N.A \\
\hline Madagascar & 23.60 & $32,308.91$ & 1373.19 & 69.38 & 27.24 & 16.24 & 56.52 \\
\hline Malawi & 16.70 & $18,611.30$ & 783.83 & 73.40 & 31.07 & 16.20 & 52.74 \\
\hline Mauritius & 1.30 & $22,365.09$ & $17,730.90$ & 114.57 & 3.40 & 25.11 & 71.49 \\
\hline Rwanda & 11.30 & $17,975.00$ & 1584.21 & 46.17 & 32.96 & 14.18 & 52.83 \\
\hline Seychelles & 0.10 & 2303.93 & $25,172.44$ & 181.29 & 2.24 & 13.23 & 68.59 \\
\hline Sudan & 39.40 & $152,767.42$ & 3882.25 & 19.12 & 27.44 & 23.90 & 48.66 \\
\hline Swaziland & 1.30 & $10,039.74$ & 7910.84 & N.A & 6.75 & 45.49 & 47.76 \\
\hline Uganda & 37.80 & $63,831.94$ & 1689.44 & 46.83 & 26.28 & 19.80 & 53.92 \\
\hline Zambia & 15.70 & $56,946.17$ & 3724.53 & N.A & 9.96 & 35.28 & 54.77 \\
\hline Zimbabwe & 15.20 & $26,057.36$ & 1709.14 & 79.56 & 13.38 & 31.12 & 55.50 \\
\hline
\end{tabular}

a The EPA is a reciprocal free trade agreement between African Caribbean, and Pacific (ACP) countries and the EU, and Ethiopia is currently negotiating with the EU to sign the interim-EPA

than $40 \%$ for Ethiopia and Burundi. On the other hand, industry sectors account for more than one-quarter of GDP for Swaziland, Egypt, D.R. Congo, Zambia, Zimbabwe, and Mauritius. The value added by the service sector is greater than that of the agriculture and industry sectors for most COMESA member countries except Ethiopia. Overall, the economic characteristics of COMESA member countries are generally diverse, and more trade liberalization in these countries would have a mixed effect.

\subsection{Trade and protection pattern of COMESA}

Table 2 reports the average tariff imposed by COMESA on their imports from other African countries, EU-27, and the rest of the world for all commodities. Egypt, Zimbabwe and the Rest of the East African regions are highly protected COMESA regions, imposing a more than $15 \%$ average tariff on their imports. Ethiopia, Kenya, Uganda, and Malawi have a medium level of protection, ranging from 10 to 15\%. Among all COMESA countries, the least protected country is Mauritius, imposing a less than 5\% average tariff on its imports from outside the COMESA region. For Ethiopia, Egypt, Mauritius, Zimbabwe, and Rest of East Africa (REA), the average tariff is higher on their imports from African countries than those from outside Africa, which is one reason for low intra-African trade. For the customs union scenario, the tariffs imposed on all regions outside Africa are reduced or increased depending on the initial tariff rate and the CET rate agreed to by all COMESA countries. Similarly, for the EPA scenario, 
Table 2 Tariff protection structure for COMESA (Percentage). Source: GTAP 9 database

\begin{tabular}{lcccccc}
\hline Regions & \multicolumn{2}{l}{$\begin{array}{l}\text { Tariff imposed by COMESA on their } \\
\text { Import, by source }\end{array}$} & \multicolumn{3}{l}{$\begin{array}{l}\text { Tariff faced by COMESA } \\
\text { on their export, } \\
\text { by destination }\end{array}$} \\
\cline { 2 - 3 } & Other Africa & EU-27 & ROW n & & Other Africa & ROW \\
\hline Ethiopia & 13.80 & 13.20 & 13.20 & 11.00 & 4.90 \\
Egypt & 18.40 & 17.30 & 16.20 & 7.60 & 4.80 \\
Kenya & 10.90 & 11.90 & 10.90 & 10.40 & 5.50 \\
Uganda & 10.30 & 10.80 & 10.80 & 10.40 & 4.60 \\
Rwanda & 9.90 & 10.10 & 9.70 & 10.50 & 4.60 \\
Malawi & 11.30 & 10.90 & 12.20 & 5.50 & 4.20 \\
Madagascar & 8.10 & 8.50 & 8.30 & 7.20 & 4.80 \\
Mauritius & 1.40 & 0.10 & 1.20 & 7.20 & 5.20 \\
Zambia & 9.50 & 12.60 & 12.40 & 5.80 & 5.20 \\
Zimbabwe & 24.40 & 23.20 & 23.10 & 7.70 & 6.60 \\
Rest of East Africa & 17.50 & 17.40 & 16.40 & 10.10 & 7.30 \\
Rest of North Africa & 7.70 & 6.20 & 8.40 & 8.90 & 8.40 \\
Rest of South Central Africa & 7.90 & 7.90 & 8.40 & 6.40 & 4.80 \\
Rest of South African Customs & 6.50 & 7.20 & 7.40 & 9.10 & 5.40 \\
\hline
\end{tabular}

the tariffs imposed on the EU-27 are removed. Therefore, we expect large trade gains for most COMESA countries, which are highly protected across each scenario.

The COMESA region benefits from relative market access when exporting to the rest of the world rather than to other African countries (Table 2). This is mainly due to the availability of preferential trade treatments given to African countries by most developed countries, such as Everything But Arms (EBA), the African Growth Opportunity Act (AGOA), the Generalized System of Preferences (GSP), and others. For exports to Europe, 17 COMESA countries face zero tariffs due to the unilateral preferential trade agreement with the EU.

Table 3 indicates the protective structure of Ethiopia by aggregated GTAP sector. Ethiopia imposes more than $20 \%$ of tariff on import of vegetables and fruits, forestry and fishery, beverages and tobacco, textiles and apparel, leather, and other manufacturing sector from COMESA. Hence, we expect a relatively large import surge on highly protected sectors following COMESA FTA. Similarly, Ethiopia's export of wood paper, petroleum and chemical, fabric metal equipment, motor vehicles, and other manufacturing faces relatively higher import tariff by other COMESA countries. Therefore, with COMESA FTA we expect large export on these sectors.

Moreover, the tariffs imposed by Ethiopia for oilseed, other crops, and motor vehicle part from either EU or Rest Of World (ROW) are smaller than the agreed CET rate. Hence, with COMESA customs union scenario, we expect an increase in protection for these sectors, and a subsequent import loss. Similarly, Ethiopia imposes large import tariff on its import from EU on vegetable and fruit, food manufacturing, beverage and tobacco, leather, and other manufacturing sectors. Therefore, we expect large surge in import for those sectors following reciprocal tariff liberalization between Ethiopia and EU. In general, there are large disparities across sectors, 
Table 3 Tariff protection structure for Ethiopia, by aggregated GTAP sector (Percentage). Source: GTAP 9 database, and COMSTAT Data Hub

\begin{tabular}{|c|c|c|c|c|c|c|c|}
\hline \multirow[t]{2}{*}{ Sectors } & \multicolumn{3}{|c|}{$\begin{array}{l}\text { Tariff imposed by Ethiopia on its } \\
\text { import, by source }\end{array}$} & \multicolumn{3}{|c|}{$\begin{array}{l}\text { Tariff faced by Ethiopia on its } \\
\text { export, by destination }\end{array}$} & \multirow{2}{*}{$\begin{array}{l}\text { COMESA CET } \\
\text { CET }\end{array}$} \\
\hline & COMESA & EU & Row & COMESA & EU & Row & \\
\hline Grains & 2.61 & 4.99 & 5.00 & 0.30 & 0.00 & 11.67 & 3.33 \\
\hline VegetablFrut & 22.31 & 26.40 & 29.68 & 1.03 & 0.01 & 7.42 & 14.86 \\
\hline Oilseed & 1.44 & 5.00 & 4.95 & 2.63 & 0.00 & 5.60 & 9.85 \\
\hline OtherCrops & 10.31 & 6.64 & 14.95 & 1.13 & 0.00 & 1.85 & 17.25 \\
\hline Livestock & 3.24 & 6.23 & 5.74 & 0.15 & 0.00 & 3.96 & 7.35 \\
\hline ForestFisher & 23.18 & 3.40 & 16.99 & 11.30 & 0.01 & 5.45 & 6.86 \\
\hline CoalOilGas & 5.04 & 4.14 & 1.58 & 1.53 & 0.00 & 0.33 & 1.08 \\
\hline FoodMnfcs & 15.24 & 22.70 & 15.75 & 6.93 & 0.00 & 1.68 & 15.43 \\
\hline BeverTobaco & 30.87 & 14.24 & 34.33 & 17.75 & 0.20 & 4.31 & 22.53 \\
\hline TextileAppar & 20.40 & 17.97 & 29.39 & 5.42 & 0.01 & 1.23 & 14.14 \\
\hline Leather & 30.10 & 22.49 & 33.58 & 8.27 & 0.00 & 4.20 & 24.26 \\
\hline WoodPaper & 13.73 & 13.28 & 13.10 & 11.50 & 0.00 & 3.15 & 12.96 \\
\hline PetroChemica & 6.61 & 6.17 & 4.99 & 10.12 & 0.00 & 3.12 & 3.24 \\
\hline BasicMetals & 8.75 & 9.55 & 11.49 & 5.23 & 0.00 & 0.02 & 5.39 \\
\hline FabMetalEqu & 16.49 & 10.30 & 9.50 & 8.71 & 0.01 & 0.74 & 4.98 \\
\hline MotorVehpar & 15.29 & 11.08 & 16.32 & 19.40 & 0.00 & 2.63 & 17.65 \\
\hline OtherMnfcs & 26.74 & 9.85 & 21.71 & 14.03 & 0.00 & 3.80 & 21.40 \\
\hline Services & 0.00 & 0.00 & 0.00 & 0.00 & 0.00 & 0.00 & 0.00 \\
\hline
\end{tabular}

For COMESA CET rate, we aggregated the tariff from HS6 level to GTAP sectors using import weight

with grains, oilseeds, and Coal, Oil, Gas sectors being the least protected sectors for Ethiopia.

As shown in Table 3, Ethiopia's exports face relatively low tariffs from Rest Of World (ROW) than its export to COMESA countries. This is due to the preferential treatment scheme given to Ethiopia by developed regions. However, exports of grain, vegetable and fruit, oilseeds, other crops, and livestock faces large import tax from ROW than from COMESA countries. Ethiopia's export to EU faces zero tariffs for most sectors due to Lomé Conventions provided for duty free access for 95 percent of the tariff lines of the ACP member countries.

Table 4 shows the bilateral import and export between Ethiopia, and other regions. The top export items from Ethiopia to COMESA are vegetable and fruit, oilseeds, other crops, and livestock while Ethiopia mainly imports food manufacturing, petroleum and chemical, basic metal, and fabric metal equipment from COMESA. Moreover, among Ethiopia's import from EU and ROW, petroleum and chemical, fabric metal equipment, and motor vehicle part constitutes the largest share, while the major export item to EU and ROW are other crops, textile and apparel, leather, and service sector.

\section{Methodology}

\subsection{The GTAP model}

This study employs a multicounty, multisector CGE modelling approach. UNCTAD and WTO (2012) states that a general equilibrium analysis explicitly accounts for all the links between the sectors of an economy: households, firms, governments, and countries. It 
Table 4 Bilateral export and import for Ethiopia, by aggregated sectors (US\$ million). Source: GTAP 9 database

\begin{tabular}{|c|c|c|c|c|c|c|}
\hline \multirow[t]{2}{*}{ Sectors } & \multicolumn{3}{|c|}{$\begin{array}{l}\text { Bilateral export from Ethiopia, } \\
\text { by destination }\end{array}$} & \multicolumn{3}{|c|}{ Bilateral import to Ethiopia, by source } \\
\hline & COMESA & EU & ROW & COMESA & EU & ROW \\
\hline Grains & 4.45 & 17.62 & 16.24 & 0.03 & 9.91 & 387.94 \\
\hline VegetablFrut & 263.52 & 30.27 & 98.73 & 0.09 & 0.50 & 27.04 \\
\hline Oilseed & 13.43 & 6.77 & 351.40 & 0.01 & 3.48 & 1.90 \\
\hline OtherCrops & 50.16 & 559.42 & 416.62 & 0.92 & 4.74 & 15.43 \\
\hline Livestock & 129.10 & 3.68 & 26.28 & 0.16 & 0.56 & 0.94 \\
\hline ForestFisher & 0.34 & 4.65 & 14.83 & 0.10 & 0.08 & 1.59 \\
\hline CoalOilGas & 0.02 & 0.71 & 23.58 & 2.33 & 2.53 & 21.10 \\
\hline FoodMnfcs & 6.38 & 8.44 & 64.67 & 18.47 & 49.94 & 245.76 \\
\hline BeverTobaco & 0.22 & 0.89 & 2.60 & 0.76 & 16.76 & 14.02 \\
\hline TextileAppar & 0.48 & 48.46 & 51.35 & 3.72 & 14.24 & 220.40 \\
\hline Leather & 1.56 & 56.34 & 74.47 & 0.51 & 4.38 & 9.89 \\
\hline WoodPaper & 0.47 & 0.73 & 1.62 & 7.96 & 33.52 & 157.36 \\
\hline PetroChemica & 8.12 & 5.33 & 12.76 & 360.57 & 346.88 & 2467.23 \\
\hline BasicMetals & 0.05 & 0.95 & 128.05 & 11.92 & 11.42 & 398.31 \\
\hline FabMetalEqu & 8.23 & 8.53 & 19.54 & 14.10 & 542.17 & 1501.58 \\
\hline MotorVehpar & 1.25 & 1.77 & 1.43 & 1.08 & 165.35 & 361.95 \\
\hline OtherMnfcs & 0.70 & 3.41 & 8.00 & 3.81 & 13.69 & 22.24 \\
\hline Services & 18.19 & 431.54 & 1043.45 & 15.06 & 715.52 & 861.20 \\
\hline Total & 506.65 & 1189.51 & 2355.63 & 441.59 & 1935.66 & 6715.88 \\
\hline
\end{tabular}

imposes a set of constraints on these sectors so that expenditures do not exceed income, and income, in turn, is determined by what the factors of production earn. These constraints establish a direct link between what the factors of production earn, and what households are able to spend. It further explains that the purpose of CGE simulations is to determine the effects of a change in trade policy on the endogenous variables of the model: prices, production, consumption, exports, imports, and welfare. The CGE simulation represents what the economy would look like if the policy change or shock had occurred. The difference in the values of the endogenous variables in the baseline and the simulation represents the effect of the policy change. Therefore, the model should be able to predict the effect on macroeconomy, trade, welfare and production patterns if the trade policy was changed. Furthermore, based on the change in welfare, the policymaker would be able to judge whether, and to what extent, the country benefited from the change in policy or not.

This study uses the global economy-wide model known as the GTAP model (Hertel and Thomas 1997). The standard features of the GTAP model are perfect competition, constant return to scale, Armington assumption in trade flows, disaggregated import usage by activity, non-homothetic consumer demands and explicit modeling of international trade and investment. The GTAP model has the advantage of overcoming the effects of policy changes at the national, bilateral or multilateral levels. Also, the policy changes are evaluated based on their impact on production levels, input factors, volumes of trade and other induced influences on welfare. Furthermore, the GTAP model is focused on the reallocation of resources between different sectors of the economy; it is an appropriate instrument for identifying the sectors and countries that win and lose 
Table 5 Experiment design. Source: Authors experiment design

\begin{tabular}{|c|c|c|c|}
\hline Scenarios & Regional integration & Description of experiments & Model closure \\
\hline Scenario 1 & COMESA FTA & There is full FTA among all COMESA member countries & Standard \\
\hline Scenario 2 & COMESA FTA & There is full FTA among all COMESA member countries & unemployment \\
\hline Scenario 3 & COMESA Customs Union & $\begin{array}{l}\text { All COMESA member countries move from FTA to } \\
\text { customs union }\end{array}$ & unemployment \\
\hline Scenario 4 & EPA & $\begin{array}{l}\text { EPA negotiating COMESA countries remove all import } \\
\text { tariffs on goods originating from EU- } 27\end{array}$ & unemployment \\
\hline
\end{tabular}

following a trade liberalization policy. The data used in this study are from version 9 of the GTAP database (Aguiar et.al. 2016). The reference year for the database is 2011.

To account for unemployment in Ethiopia, and other COMESA countries, the model assumes endogenous unskilled labor supply, and exogenous wage for the last three scenarios. However, for COMESA FTA (scenario 1), we provide a result with standard employment closure. The endowment effect in scenario 2, 3, and 4 captures the change in regional welfare due to changes in the employment of the unskilled labor force.

\subsection{Regional and sectoral aggregation}

The GTAP-9 database features 140 countries/regions and 57 tradable commodities. In this study, the 140 countries/regions are mapped into 18 regions, and the 57 sectors are mapped into 18 sectors (see Appendices I and II). The GTAP 9 database identifies only 10 out of the 19 COMESA member countries as separate regions, while the other nine COMESA countries are aggregated into four GTAP composite regions. Furthermore, the regional aggregation includes four non-COMESA regions: the EU-27, the USA, the rest of Africa, and ROW.

\subsection{Experiment design}

This study begins with the GTAP 9 database in the base year 2011, aggregated to the set of regions and sectors specified in Appendices I and II. The analysis is structured around a set of scenarios that reflect potential trade agreements between Ethiopia, and COMESA. As shown in Table 5, we conduct four scenarios to evaluate the macroeconomic and welfare impacts of trade liberalization policies.

In scenario 1 (COMESA FTA), there is FTA among 19 COMESA member countries. Ethiopia, Eretria, and Swaziland are negotiating to join COMESA FTA. Therefore, the first scenario models the effect of $100 \%$ tariff elimination between the three COMESA FTA negotiating countries and 16 COMESA FTA member countries. Scenario two is similar to the first one, but we use unemployment closure to account for unemployment in COMESA regions. Hence, in the second scenario, we assume endogenous unskilled labor supply and exogenous wage. ${ }^{3}$ For COMESA FTA (scenario 1 and 2), COMESA rules of origin protocol is used as the main part of the Free Trade Agreements to confirm

\footnotetext{
${ }^{3}$ The GTAP CGE model is a system of equations that describes economic linkages between several global regions and sectors. The model closure determines which variables are exogenous and which are endogenous. Because there is no theoretical framework for choosing between different closures, the choice of closure should be guided by the structure of the economy under investigation. Using similar approach to aforementioned study by Karingi et al. (2002), our study uses a fixed wage closure for unskilled labour, allowing for high levels of unemployment in the COMESA region. This we believe represents a more accurate reflection of the labour market within the COMESA region. Therefore, the model assumes endogenous unskilled labor supply, and exogenous wage for scenario 2, 3, and 4. However, for scenario 1 , we use standard GTAP model (exogenous labor supply and endogenous wage).
} 
the originating status of the product. For a product to be considered as originating in a Member State, it must meet one of the criteria prescribed in the COMESA rules of origin. For products to be accepted as originating they should be consigned directly from a Member state to a consignee in another Member State. ${ }^{4}$ In practice, some sectors are exempted from FTA due to Rules of origin protocol. However, in this paper we remove import tariff on all products originated from COMESA member countries.

In scenario 3 (COMESA customs union), a new baseline data is constructed using the updated result from scenario 2. Then, all COMESA member countries levy Common External Tariff (CET) on non-COMESA regions. ${ }^{5}$ The agreed upon CET rates have three categories: $0 \%$ for raw materials and capital goods, $10 \%$ for intermediate goods and $25 \%$ for finished products. ${ }^{6}$ In the creation of a customs union, some of the initial tariff rates are higher than the recommended CET rate, while in other cases, they had to be raised to bring them to the CET rate. As a result, customs union scenarios may reduce or increase protection for some countries.

There are two main challenges in preparing the customs union shock file for scenario 3. First, the CET rates negotiations are agreed at detail HS6 code level, but the analysis is done at aggregated 18 GTAP sector level. Second, some COMESA member countries provide a list of sensitive products at HS6 code level that can be excluded from the CET rate. ${ }^{7}$ Therefore, to prepare applied tariff shocks for our aggregated sector and region GTAP models, we need much more detailed data on trade flows and on bound and applied rates.

Tariff Analytical and Simulation Tool for Economists (TASTE) compresses the MAcMapHS6 dataset into a single CD and allows the ordinary GTAP user to process the whole dataset rapidly. ${ }^{8}$ We use TASTE for GTAP 9 database for the transformation of scenarios about formula-based changes in bound rates into files of percent change shocks to applied rates, which could be used by RunGTAP. Resulting changes in applied rates are averaged to our aggregated sectors and regions and stored in a format which can be directly used by the standard GTAP model. ${ }^{9}$

In order to strengthen the economic relationship between two countries, regional trade agreements are permitted for customs unions/free-trade areas under certain conditions. RTAs and Customs Union (CU) are governed by Article XXIV of General Agreement on Trade and Tariffs (GATT) 1994, Article V of the General Agreement on Trade in Services (GATS) and the Enabling Clause. This Article mainly provides that duties and other regulation of commerce should be eliminated for 'substantially all the trade' among

\footnotetext{
${ }^{4}$ For detail explanation of COMESA Protocol on Rules of origin refer to http://trade.go.ke/sites/default/files/COMES A_Protocol-on-Rules-of-Origin-2015_0.pdf.

5 The baseline data for scenario 3 is scenario 2, full FTA among all COMESA member countries.

6 The CET rate can be downloaded from http://www.comesa.int/comesa-common-tariff-nomenclature-and-commo n-external-tariff-hs-2017/.

7 Refer to the 2011 Gazette, Volume 16 Annex 1: list of sensitive products for Kenya, Madagascar, Malawi, Mauritius, and Swaziland. http://www.comesa.int/wp-content/uploads/2016/06/2011Gazette-Vol.-16-Annex-II-ist-of-sensitiveproducts.pdf. Besides, for countries that did not submit a list of sensitive products, the top $2 \%$ of a number of HS- 6 products are selected as sensitive products using the loss of tariff revenue criteria (Jean et.al. 2008).

8 TASTE for GTAP 9 is based on applied and bound tariff data of 2011 provided by ITC (Market Access map). The data is based on and consistent with the ITC-Market Access Map tariff dataset employed in GTAP 9. It has trade and tariff data for 236 trading regions, 5052 HS6 commodities, and 1299 GTAP-compatible HS4 sectors.

${ }^{9}$ For detail explanation about TASTE refer to https://www.gtap.agecon.purdue.edu/resources/taste/taste.asp.
} 
RTA members and that the barriers placed in the way of third countries should not be 'on the whole higher or more restrictive.'

In COMESA Customs union (scenario 3), the common external tariff rate is higher than the FTA case. Hence, the customs union increases protection. This is against the World Trade Organization (WTO) principle of not applying more restrictive tariffs while forming a $\mathrm{CU}$ on third countries. However, the Enabling Clause provides that the Most Favoured Nations (MFN) Clause of GATT Article 1.1 is exempted for a limited number of preferential arrangements, including 'regional or global arrangements entered into among less-developed countries for the mutual reduction or elimination of tariffs. ${ }^{10}$ Indeed, many RTAs including COMESA have been notified under the Enabling Clause. Hence, even though the tariff rates increase for some sectors, the COMESA customs union scenario conforms to WTO principles.

The Cotonou Agreement calls for the strengthening of intra-regional cooperation and integration among ACP countries. As a result, in the first three scenarios, the principle of deep regional integration in COMESA is taken into account by establishing FTA among themselves and levying CET on non-member countries. However, one of the key principles of the European Partnership Agreement (EPA) is reciprocity. Moreover, the Lomé Conventions provided for duty free access for 95 precent of the tariff lines of the ACP member countries. Ethiopia is negotiating to reciprocate its tariff with the EU under Eastern and Southern African (ESA) EPA groups. Hence, our main assumption in scenario 4 is to establish EPA that is compatible with WTO. In scenario 4 (EPA), a new baseline data is constructed using the updated result from scenario $3{ }^{11}$ Then, all COMESA countries remove all import tariffs on goods originating from EU-27. ${ }^{12}$

\section{Results}

All scenarios results are designed as a variation of the baseline scenario. The analysis are comparatively static; hence, they do not address questions relating to the sequencing of reforms and the potential dynamic benefits of trade liberalization. When bilateral tariffs are eliminated, relative prices change, and in response, trade flows between countries change, which eventually affects resource allocations in the economy. It is expected that different sectors in the economy will adjust their outputs according to relative price change. In bilateral terms, when an importer reduces tariffs on its partners, the amount of increase or decrease in its imports depends on the trade creation and diversion effects. Trade creation arises when more efficiently produced imported goods replaced relatively inefficient domestic production. On the other hand, trade diversion occurs when the sources of supply divert from the more efficiently producing non-member countries to the less efficiently producing member countries under the tariff-free access granted to signatory countries (Narayanan and Sharma 2016). The following section explains the

\footnotetext{
${ }^{10}$ https://www.wto.org/english/docs_e/legal_e/enabling1979_e.htm\#fntext-1.

11 The COMESA customs union baseline is created to show that EPA is not implemented directly. Instead, we provide an option for COMESA countries to develop market capacity, and compete with European exporter through establishing customs union before moving to EPA.

${ }^{12}$ Egypt and Libya are not beneficiary of EPA. Hence, scenario 4 models reciprocal tariff removal by 17 EPA negotiating COMESA member countries on goods originating from EU-27.
} 
macroeconomic, welfare, revenue, and industry output impacts of the different scenarios described above.

\subsection{Aggregate macroeconomic and welfare results}

In the GTAP model, welfare changes are measured by equivalent variation (EV). EV is a money metric measure that compares the cost of pre and post-shock levels of consumer utility, both valued at base year prices (Burfisher 2011). In the standard GTAP model, welfare is a function of the terms of trade change (i.e., interregional shifting of welfare), allocative efficiency change (i.e., changes in production or consumption efficiency due to the presence of distortion), and investment-saving balance. The net welfare impact of tariff reduction depends on the relative size of the trade creation and trade diversion effects.

Table 6 shows the Real GDP (RGDP) and welfare effect for COMESA and nonCOMESA regions from COMESA FTA (scenario1 and 2), COMESA customs union (Scenario 3) and EPA (Scenario 4). We conduct the COMESA FTA scenario both with standard employment closure (Scenario 1), and with unemployment closure (scenario 2). Simulation results for scenario 1, that models full FTA among all COMESA regions with standard employment closure, yields negative welfare effect for Ethiopia, Uganda, Zambia, and Zimbabwe, but with unemployment closure (scenario 2), almost all COMESA regions gain in terms of welfare mainly due to endowment effect. An exception to this trend is Zimbabwe that reports a welfare loss of around US\$56 million in scenario 2. Ethiopia, Egypt, Kenya, and Mauritius, enjoys a relatively large welfare gain of US\$22 million, US $\$ 48$ million, US $\$ 34$ million, and US $\$ 42$ million respectively in scenario 2 . Moreover, all COMESA countries gains in RGDP with both scenario 1 and 2. In contrast, countries and regions outside COMESA report welfare losses, the highest being EU-27 (US\$93 million) followed by USA (US\$57 million). An exception to this trend is ROW, which report welfare gain with both scenario 1 and 2 . This suggests that full free trade area among all COMESA countries could have a trade diversionary effect for some non-COMESA regions.

The move from free trade area to customs union (scenario 3) result in welfare losses for Ethiopia (US\$77 million), Kenya (US\$107 million), Madagascar (US\$ 12 million), and Mauritius (US\$124 million). Other COMESA regions report welfare gain with scenario 3, highest being in Egypt (US\$330 million) followed by Zambia (US\$ 62 million). Exceptions to this trend are RNA, and RSAC, which report welfare loses with scenario 3. Moreover, all COMESA regions report relatively large RGDP growth with scenario 3 than with scenario 1 and 2. Exceptions to this trend are Mauritius, RNA, and RSAC that report both RGDP and welfare lose with scenario 3 .

Simulation results for scenario 4, that models reciprocal tariff removal by 17 COMESA member countries on goods originating from EU, yields positive welfare effect for EU (US\$ 1275 million), Rwanda (US\$9 million), Zambia (US\$23 million), and RSCA (US\$59 million) while other COMESA regions report large welfare and RGDP losses. Besides, countries and regions outside EU and COMESA report welfare losses with scenario 4. This suggests that EPA could have trade diversionary effect for non-COMESA regions. The world as a whole enjoys welfare gains of US\$ 154 million, and US $\$ 447$ million with scenario 1 and 2 respectively. Whereas, COMESA customs union and EPA scenarios 
Table 6 Changes in real GDP and welfare, by region. Source: Model Simulation

\begin{tabular}{|c|c|c|c|c|c|c|c|c|}
\hline & \multicolumn{4}{|c|}{$\%$ Change in Real GDP } & \multicolumn{4}{|c|}{ Welfare in Equivalent variation (US\$, million) } \\
\hline & $\begin{array}{l}\text { Scenario } \\
1\end{array}$ & $\begin{array}{l}\text { Scenario } \\
2\end{array}$ & $\begin{array}{l}\text { Scenario } \\
3\end{array}$ & $\begin{array}{l}\text { Scenario } \\
4\end{array}$ & $\begin{array}{l}\text { Scenario } \\
1\end{array}$ & $\begin{array}{l}\text { Scenario } \\
2\end{array}$ & $\begin{array}{l}\text { Scenario } \\
3\end{array}$ & Scenario 4 \\
\hline Ethiopia & 0.01 & 0.10 & 0.49 & -0.05 & -4.80 & 22.63 & -77.13 & -212.06 \\
\hline Egypt & 0.00 & 0.01 & 0.01 & -0.01 & 24.90 & 48.81 & 330.98 & -55.38 \\
\hline Kenya & 0.03 & 0.06 & 0.34 & -0.21 & 21.70 & 34.94 & -107.47 & -270.99 \\
\hline Malawi & 0.04 & 0.07 & 0.32 & -0.02 & 10.10 & 11.85 & 21.61 & -6.43 \\
\hline $\begin{array}{l}\text { Madagas- } \\
\text { car }\end{array}$ & 0.00 & 0.01 & 0.22 & -0.09 & 0.20 & 0.81 & -12.34 & -42.95 \\
\hline Mauritius & 0.02 & 0.12 & -2.59 & -0.05 & 31.80 & 42.22 & -124.49 & -12.07 \\
\hline Rwanda & 0.01 & 0.03 & 0.16 & 0.18 & 1.60 & 2.83 & 11.03 & 9.55 \\
\hline Uganda & 0.00 & 0.04 & 0.09 & -0.06 & -1.40 & 4.24 & 1.33 & -24.64 \\
\hline Zambia & 0.00 & 0.01 & 0.48 & 0.15 & -0.10 & 1.00 & 62.12 & 23.43 \\
\hline Zimbabwe & 0.65 & 0.46 & 0.46 & -1.21 & -38.70 & -56.25 & 39.87 & -183.95 \\
\hline REA & 0.04 & 0.11 & 0.36 & 0.20 & 38.10 & 90.20 & 41.09 & -0.47 \\
\hline RNA & 0.00 & 0.02 & -0.39 & 0.00 & 23.20 & 63.55 & -994.92 & -14.05 \\
\hline RSCA & 0.02 & 0.08 & 0.01 & 0.02 & 14.70 & 91.66 & 64.42 & 59.03 \\
\hline RSAC & 0.60 & 1.50 & -0.41 & -0.13 & 105.50 & 166.63 & -51.38 & -17.02 \\
\hline EU27 & 0.00 & 0.00 & 0.00 & 0.00 & -93.00 & -92.46 & -62.44 & 1275.56 \\
\hline USA & 0.00 & 0.00 & 0.00 & 0.00 & -54.40 & -57.29 & 93.27 & -21.81 \\
\hline Ro.Africa & 0.00 & 0.00 & 0.00 & 0.00 & -21.80 & -20.74 & -22.92 & -104.48 \\
\hline ROW & 0.00 & 0.00 & 0.00 & 0.00 & 96.80 & 93.29 & 498.67 & -448.49 \\
\hline Total & & & & & 154.40 & 447.93 & -288.69 & -47.22 \\
\hline
\end{tabular}

result in overall welfare losses of around US $\$ 288$ million, and US\$47 million respectively. Overall, Rwanda and RSCA emerged as the winner in terms of welfare in all scenarios.

The decomposition of welfare effects in Table 7 reveals that gains for Ethiopia (US\$22 million) are mainly driven by positive allocative efficiency effect and endowment effect. Allocative efficiency measures the reallocation of resources in the economy when economic distortions, such as tariffs, are removed. Decomposing the allocative efficiency gain into different tax component shows that private consumption tax contributes to large gains in allocative efficiency while there is large welfare cost due to import tax. This is due to the removal of import tariff following COMESA FTA. Moreover, the decomposition of allocative efficiency by factor and commodity shows that textile and apparel, leather, and fabric metal equipment sectors gain from scenario 2 , and 3 . However, most sectors such as service, textile and apparel, motor vehicle part, fabric metal equipment, and petroleum chemical, report large allocative efficiency losses from the proposed EPA. It can be seen from Tables 12 and 13 that for these sectors trade is diverted from COMESA regions to non-COMESA regions.

As tariffs are removed across scenarios, there is large demand for unskilled labor in many sectors, which results in a positive endowment effect. Table 8 reports the change in employment of factor, and factor price, across all scenarios. In scenario 1 , we use the standard model closure. Hence, the impact is on factor return, and we observe an increase in factor return following COMESA FTA. For scenario 2, 3, and 4, we use unemployment closure for unskilled labor force. Consequently, there is a large increase in demand for unskilled labor force of around US\$23 million, US\$112 million, and US $\$ 43$ million for scenario 2, 3, and 4 respectively. While, for other factor of production, 
Table 7 Decomposition of the Total Welfare Effect for Ethiopia (US\$ millions). Source: Model Simulation

\begin{tabular}{lcclcr}
\hline & $\begin{array}{l}\text { Allocative } \\
\text { efficiency effect }\end{array}$ & Endowment effect & $\begin{array}{l}\text { Terms of trade } \\
\text { effect }\end{array}$ & $\begin{array}{l}\text { Investment- } \\
\text { saving effect }\end{array}$ & Total \\
\hline Scenario 1 & 3.80 & 0.00 & -3.00 & -5.60 & -4.80 \\
Scenario 2 & 6.74 & 23.18 & -2.99 & -4.30 & 22.63 \\
Scenario 3 & 41.92 & 109.79 & -89.69 & -139.16 & -77.13 \\
Scenario 4 & -59.08 & 42.76 & -78.88 & -116.86 & -212.06 \\
\hline
\end{tabular}

Table 8 Change in factors and factor prices (percentage). Source: Model Simulation

\begin{tabular}{llccr}
\hline & Scenario 1 & Scenario 2 & Scenario 3 & Scenario 4 \\
\hline $\begin{array}{l}\text { Factor change (\%) } \\
\text { UnSkLab (\% change) }\end{array}$ & 0.00 & & & \\
UnSkLab (Change in millions & 0.00 & 0.19 & 0.91 & 0.36 \\
$\quad$ of US\$) & & & 112.30 & 43.73 \\
Change in factor price (\%) & 0.31 & 0.69 & & \\
Land & 0.15 & 0.00 & 4.25 & 2.12 \\
UnSkLab & 0.14 & 0.23 & 0.00 & 0.00 \\
SkLab & 0.13 & 0.24 & 0.54 & 0.12 \\
Capital & 0.11 & 0.56 & 0.67 & 0.14 \\
NatRes & & & 1.09 & -0.69 \\
\hline
\end{tabular}

we observe an increase in their factor return across all scenarios. An exception to this trend is natural resource that report decline in its factor return with scenario 4 .

Sector-level analysis in Table 9 shows that the large losses for Terms of Trade (TOT) for scenario 3 and 4 are primarily driven by a large drop in export price for vegetable and fruit, oilseed, other crops, and service sectors. Finally, the investment-saving effect, which is adjusted to equate the real trade balance, is also negative in all scenarios. The large loss in investment-saving balance in scenario 3 and 4 goes in line with the large trade surplus. Overall, for scenario 3 and 4; the welfare loss due to the terms of trade and investment-saving effect, dominates the gain from endowment and allocative efficiency, resulting in net welfare loss for Ethiopia while the reverse is true for scenario 2.

\subsection{Trade balance and import tax revenue results}

Removal of import tariffs among COMESA countries is expected to result in significant changes in the level, and direction of trade among member countries by reducing the domestic market price of an import. The reduction of import prices of raw materials in turn results in a rise in demand for import by firms, private households and the government. The availability of cheap imports reduces domestic production costs and increases the competitiveness of exports in these countries. However, the extent of the rise in exports depends on the relative change in price in different sectors driven by tariff reduction. As a result, there is a slight difference in the growth of exports and imports across COMESA countries.

As shown in Table 10, Rwanda, Uganda, Zambia and RSCA report a trade deficit in all scenarios. However, for other COMESA regions except for Malawi, Madagascar, Zimbabwe and REA, there is a trade deficit only under the COMESA FTA (Scenario 
Table 9 Decomposition of terms of trade effect for Ethiopia, by commodity (US\$ million). Source: Model Simulation

\begin{tabular}{|c|c|c|c|c|c|c|c|c|}
\hline \multirow[t]{2}{*}{ Sectors } & \multicolumn{2}{|l|}{ Scenario 1} & \multicolumn{2}{|c|}{ Scenario 2} & \multicolumn{2}{|c|}{ Scenario 3} & \multicolumn{2}{|l|}{ Scenario 4} \\
\hline & $\begin{array}{l}\text { Price } \\
\text { of export }\end{array}$ & $\begin{array}{l}\text { Price } \\
\text { of import }\end{array}$ & $\begin{array}{l}\text { Price } \\
\text { of export }\end{array}$ & $\begin{array}{l}\text { Price } \\
\text { of import }\end{array}$ & $\begin{array}{l}\text { Price } \\
\text { of export }\end{array}$ & $\begin{array}{l}\text { Price } \\
\text { of import }\end{array}$ & $\begin{array}{l}\text { Price } \\
\text { of export }\end{array}$ & $\begin{array}{l}\text { Price } \\
\text { of import }\end{array}$ \\
\hline Grains & -0.02 & 0.00 & -0.04 & 0.00 & -0.81 & 0.00 & -0.72 & 0.02 \\
\hline $\begin{array}{l}\text { Vegeta- } \\
\text { blFrut }\end{array}$ & 0.10 & 0.00 & -0.11 & 0.00 & -8.30 & 0.00 & -6.84 & 0.00 \\
\hline Oilseed & 0.07 & 0.00 & -0.08 & 0.00 & -6.05 & 0.00 & -5.33 & 0.00 \\
\hline $\begin{array}{l}\text { Other- } \\
\text { Crops }\end{array}$ & -0.01 & 0.00 & -0.47 & 0.00 & -17.74 & 0.00 & -16.02 & 0.00 \\
\hline Livestock & 0.01 & 0.00 & -0.06 & 0.00 & -3.32 & 0.00 & -2.71 & 0.00 \\
\hline $\begin{array}{l}\text { Forest- } \\
\text { Fisher }\end{array}$ & -0.01 & 0.00 & 0.03 & 0.00 & -0.40 & 0.00 & -0.43 & 0.00 \\
\hline $\begin{array}{l}\text { CoalOil- } \\
\text { Gas }\end{array}$ & -0.04 & 0.00 & -0.03 & 0.00 & -0.57 & 0.00 & -0.47 & 0.00 \\
\hline $\begin{array}{l}\text { FoodMn- } \\
\text { fCS }\end{array}$ & -0.07 & 0.00 & -0.06 & 0.00 & -2.13 & -0.23 & -1.86 & 0.05 \\
\hline $\begin{array}{l}\text { BeverTo- } \\
\text { baco }\end{array}$ & 0.00 & 0.00 & 0.00 & 0.00 & -0.09 & 0.01 & -0.08 & 0.01 \\
\hline $\begin{array}{l}\text { TextileAp- } \\
\text { par }\end{array}$ & -0.10 & 0.01 & -0.09 & 0.01 & -2.84 & 0.01 & -2.53 & 0.01 \\
\hline Leather & -0.15 & 0.00 & -0.12 & 0.00 & -3.76 & 0.02 & -3.38 & 0.01 \\
\hline $\begin{array}{l}\text { WoodPa- } \\
\text { per }\end{array}$ & -0.01 & 0.00 & -0.01 & 0.00 & -0.09 & 0.02 & -0.09 & 0.04 \\
\hline $\begin{array}{l}\text { Petro- } \\
\text { Chemica }\end{array}$ & -0.12 & -0.45 & -0.11 & -0.44 & -1.05 & 3.57 & -0.68 & 2.24 \\
\hline $\begin{array}{l}\text { BasicMet- } \\
\text { als }\end{array}$ & -0.21 & -0.01 & -0.18 & -0.01 & -3.84 & 0.07 & -3.24 & 0.06 \\
\hline $\begin{array}{c}\text { FabMet- } \\
\text { alEqu }\end{array}$ & -0.03 & -0.04 & -0.02 & -0.04 & -1.36 & 0.12 & -1.17 & 0.09 \\
\hline $\begin{array}{l}\text { Motor- } \\
\text { Vehpar }\end{array}$ & 0.00 & 0.00 & 0.01 & 0.00 & -0.19 & 0.01 & -0.18 & 0.01 \\
\hline $\begin{array}{l}\text { OtherM- } \\
\text { nfcs }\end{array}$ & -0.02 & 0.00 & -0.01 & 0.00 & -0.38 & 0.12 & -0.34 & 0.08 \\
\hline Services & -1.92 & 0.01 & -1.15 & 0.01 & -40.49 & -0.02 & -35.38 & -0.06 \\
\hline Total & -2.53 & -0.50 & -2.50 & -0.49 & -93.40 & 3.72 & -81.46 & 2.57 \\
\hline
\end{tabular}

1 and 2). Overall, Zimbabwe is the only country in the COMESA region with a trade surplus across all scenarios. From non-COMESA regions, USA and ROW report trade surplus in all scenarios except with COMESA customs union whereas EU experiences trade surplus only with COMESA FTA (Scenario 1 and 2). Rest of Africa is the only non-COMESA region which reports trade surplus in all scenarios.

Table 10 presents, that most COMESA countries reports significant reduction in their import tax revenue across all scenarios. Exceptions to this trend are Malawi and Madagascar, Egypt, and Mauritius. The revenue effect for customs union scenario depends on the change in tariffs; for some countries, such as Egypt, Mauritius, and RNA, their baseline tariff rate is below CET rate, and hence customs union increase protection and result in a revenue gain, while for other COMESA regions, there is a substantial revenue loss. For scenario 4, all COMESA countries report significant revenue losses, while the EU 27 reported a revenue gain of US\$50 million. 
Table 10 Changes in trade balance and import tax revenue (US\$ million). Source: Model Simulation

\begin{tabular}{|c|c|c|c|c|c|c|c|c|}
\hline \multirow[t]{2}{*}{ Regions } & \multicolumn{4}{|c|}{ Changes in trade balance } & \multicolumn{4}{|c|}{ Changes in import tax revenue } \\
\hline & $\begin{array}{l}\text { Scenario } \\
1\end{array}$ & $\begin{array}{l}\text { Scenario } \\
2\end{array}$ & $\begin{array}{l}\text { Scenario } \\
3\end{array}$ & $\begin{array}{l}\text { Scenario } \\
4\end{array}$ & $\begin{array}{l}\text { Scenario } \\
1\end{array}$ & $\begin{array}{l}\text { Scenario } \\
2\end{array}$ & $\begin{array}{l}\text { Scenario } \\
3\end{array}$ & Scenario 4 \\
\hline Ethiopia & -5.51 & -14.58 & 39.74 & 54.47 & -50.77 & -50.10 & -383.57 & -322.46 \\
\hline Egypt & -32.79 & -37.87 & 39.81 & 25.79 & -49.25 & -48.52 & 1067.64 & -10.59 \\
\hline Kenya & -20.07 & -25.19 & 156.10 & 149.10 & -11.16 & -10.58 & -185.10 & -244.13 \\
\hline Malawi & -15.03 & -17.06 & -39.67 & 2.01 & 0.29 & 0.37 & -40.89 & -15.07 \\
\hline $\begin{array}{l}\text { Madagas- } \\
\text { car }\end{array}$ & 0.17 & -0.05 & -53.22 & -34.94 & 0.20 & 0.20 & -163.13 & -144.65 \\
\hline Mauritius & -36.15 & -40.40 & 187.32 & 9.06 & 0.08 & 0.12 & 468.88 & -2.34 \\
\hline Rwanda & -0.76 & -0.85 & -0.74 & -1.97 & -0.56 & -0.55 & -7.23 & -19.77 \\
\hline Uganda & -2.34 & -2.68 & -0.80 & -6.99 & -14.82 & -14.74 & -27.21 & -59.86 \\
\hline Zambia & -1.42 & -1.53 & -39.25 & -30.89 & -0.35 & -0.32 & -88.02 & -51.14 \\
\hline Zimbabwe & 81.99 & 83.21 & 7.83 & 65.47 & -103.55 & -104.37 & -22.15 & -143.41 \\
\hline REA & -17.97 & -20.27 & -4.00 & 6.09 & -65.98 & -65.48 & -1006.32 & -645.58 \\
\hline RNA & -13.23 & -16.47 & 981.39 & 3.54 & -8.49 & -8.29 & 1842.69 & -1.92 \\
\hline RSCA & -170.5 & -181.31 & -103.88 & -62.17 & -98.38 & -97.28 & -99.13 & -94.01 \\
\hline RSAC & -66.43 & -103.95 & 40.53 & 1.16 & 7.05 & 8.18 & -0.68 & -7.41 \\
\hline EU27 & 55.91 & 72.12 & -156.12 & -719.83 & 0.81 & 0.75 & -9.39 & 50.26 \\
\hline USA & 65.35 & 84.50 & -288.16 & 153.44 & 7.16 & 6.94 & -0.01 & -4.60 \\
\hline RO. Africa & 9.3 & 9.74 & 1.06 & 42.32 & -7.21 & -6.94 & 0.69 & -13.16 \\
\hline ROW & 169.41 & 212.58 & -767.95 & 344.33 & -7.53 & -6.36 & 20.91 & -46.64 \\
\hline
\end{tabular}

\subsection{Ethiopia's sectoral results}

\subsubsection{Changes in export and import}

In this section, we focus on Sectoral results for Ethiopia, focusing on the trade and output effects. The difference in the Sectoral impact across each scenario depends on the relative changes in export and import prices following tariff reduction. A significant effect of trade liberalization is that it causes a reallocation of resources, such as labor, capital, and land, which further leads to a structural adjustment in the factor market. In general, the sectors protected by high tariff rates can lose more production when tariffs are reduced. In contrast, trade liberalization brings about efficiency gains that increase income and production across sectors by allocating resources to sectors in which the country has a comparative advantage.

The results in Table 11 shows that, in scenario 2, the Ethiopian economy reports larger export growth than import growth for most manufacturing sectors such as wood paper, petroleum and chemicals, fabricated metal equipment, and motor vehicle parts, implying that exports are more competitive than imports. In contrast, for some other sectors, such as other crops, livestock, forestry and fishery, textiles and apparel, and leather, imports grow more than exports. The move from the COMESA FTA (scenario 2) to customs union (scenario 3) results in large export and import growth for the coal, oil and gas, textiles and apparel, and leather sectors. An exception to this trend is leather sectors, which reports a reduction in import growth under scenario 3 than scenario 2. For most manufacturing sectors such as food manufacturing, wood paper, basic metal, motor vehicle part, and other manufacturing, export grows more than $10 \%$ with customs 
Table 11 Changes in aggregate export and import for Ethiopia. Source: Model Simulation

\begin{tabular}{|c|c|c|c|c|c|c|c|c|}
\hline & \multicolumn{4}{|c|}{ Aggregate import (\%) } & \multicolumn{4}{|c|}{ Aggregate export (\%) } \\
\hline & $\begin{array}{l}\text { Scenario } \\
1\end{array}$ & $\begin{array}{l}\text { Scenario } \\
2\end{array}$ & $\begin{array}{l}\text { Scenario } \\
3\end{array}$ & $\begin{array}{l}\text { Scenario } \\
4\end{array}$ & $\begin{array}{l}\text { Scenario } \\
1\end{array}$ & $\begin{array}{l}\text { Scenario } \\
2\end{array}$ & $\begin{array}{l}\text { Scenario } \\
3\end{array}$ & Scenario 4 \\
\hline Grains & -0.19 & -0.20 & -7.48 & -5.59 & 0.52 & 0.72 & 11.06 & 9.17 \\
\hline $\begin{array}{l}\text { Vegeta- } \\
\text { blFrut }\end{array}$ & 0.23 & 0.25 & -0.98 & -2.31 & 1.90 & 1.99 & -2.15 & 0.71 \\
\hline Oilseed & 0.10 & 0.13 & -4.99 & -6.06 & 0.32 & 0.47 & 7.15 & 5.80 \\
\hline $\begin{array}{l}\text { Other- } \\
\text { Crops }\end{array}$ & 1.84 & 1.83 & -3.22 & 16.36 & -0.16 & 0.05 & 9.49 & 7.91 \\
\hline Livestock & 0.68 & 0.71 & 3.76 & 5.18 & 0.49 & 0.59 & -2.24 & -3.67 \\
\hline $\begin{array}{l}\text { Forest- } \\
\text { Fisher }\end{array}$ & 3.43 & 3.78 & 6.53 & -2.11 & 0.97 & 0.43 & 7.43 & 7.46 \\
\hline CoalOilGas & 1.29 & 1.44 & 10.19 & 13.88 & 1.62 & 1.27 & 27.55 & 17.88 \\
\hline $\begin{array}{l}\text { FoodMn- } \\
\text { fCS }\end{array}$ & 3.20 & 3.34 & -4.55 & 3.47 & 4.29 & 4.21 & 13.82 & 10.36 \\
\hline $\begin{array}{l}\text { BeverTo- } \\
\text { baco }\end{array}$ & 0.95 & 1.07 & 5.48 & 18.98 & 2.58 & 2.56 & 4.49 & 3.65 \\
\hline $\begin{array}{l}\text { TextileAp- } \\
\text { par }\end{array}$ & 2.07 & 2.21 & 25.93 & 8.85 & 0.88 & 0.82 & 21.00 & 15.74 \\
\hline Leather & 12.96 & 13.17 & 11.37 & 69.45 & 2.12 & 1.96 & 21.99 & 16.72 \\
\hline $\begin{array}{l}\text { WoodPa- } \\
\text { per }\end{array}$ & 1.04 & 1.09 & -1.57 & 2.48 & 18.74 & 18.80 & 10.55 & 7.14 \\
\hline $\begin{array}{l}\text { Petro- } \\
\text { Chemica }\end{array}$ & 0.38 & 0.45 & 0.35 & -0.43 & 25.85 & 25.73 & 11.05 & 8.87 \\
\hline $\begin{array}{l}\text { BasicMet- } \\
\text { als }\end{array}$ & 0.41 & 0.49 & -2.34 & -2.33 & 1.02 & 0.87 & 22.62 & 15.74 \\
\hline $\begin{array}{c}\text { FabMet- } \\
\text { alEqu }\end{array}$ & 0.32 & 0.45 & 1.75 & 1.39 & 23.83 & 23.52 & 15.86 & 14.83 \\
\hline $\begin{array}{l}\text { Motor- } \\
\text { Vehpar }\end{array}$ & 0.04 & 0.14 & -1.46 & 8.00 & 48.79 & 48.58 & 12.87 & 7.38 \\
\hline $\begin{array}{l}\text { OtherM- } \\
\text { nfcs }\end{array}$ & 20.07 & 20.23 & -4.98 & 25.60 & 12.29 & 12.10 & 21.07 & 13.42 \\
\hline Services & -0.18 & -0.04 & 12.62 & 5.47 & 0.35 & 0.21 & 8.93 & 7.29 \\
\hline
\end{tabular}

union although their import reduces slightly. The reciprocal free trade agreement with the EU-27 (scenario 4) results in relatively larger export growth than import for most sectors. Overall, for scenario 4, there is large export and import growth for coal, oil and gas, textiles and apparel, leather, and other manufacturing sector.

The results in Tables 12 and 13 report the change in imports and exports for Ethiopia by source and destination respectively. For scenario 1 and 2, the large growth in import and export comes from other COMESA countries, while trade with non-COMESA region reduces significantly. Moreover, Ethiopia reports large export and import of food manufacturing, petroleum and chemical, and fabric metal equipment sectors with other COMESA countries. In contrast, with scenario 3 and 4, there is a large trade with nonCOMESA regions while Ethiopia's import and export with COMESA reduces for many sectors. Therefore, COMESA customs union, and EPA divert trade from COMESA to non-COMESA regions, while COMESA FTA increases Ethiopia-COMESA trade. Overall, with scenario 3 and 4, the share of textile and apparel, fabric metal equipment, and services sector import from non-COMESA regions is higher than other sector. Besides, 
Table 12 Changes in Ethiopia import by source (US\$ Million). Source: Model Simulation

\begin{tabular}{|c|c|c|c|c|c|c|c|c|}
\hline \multirow[t]{2}{*}{ Sectors } & \multicolumn{4}{|c|}{ Ethiopia import from COMESA } & \multicolumn{4}{|c|}{ Ethiopia import from Non-COMESA } \\
\hline & $\begin{array}{l}\text { Scenario } \\
1\end{array}$ & $\begin{array}{l}\text { Scenario } \\
2\end{array}$ & $\begin{array}{l}\text { Scenario } \\
3\end{array}$ & $\begin{array}{l}\text { Scenario } \\
4\end{array}$ & $\begin{array}{l}\text { Scenario } \\
1\end{array}$ & $\begin{array}{l}\text { Scenario } \\
2\end{array}$ & $\begin{array}{l}\text { Scenario } \\
3\end{array}$ & Scenario 4 \\
\hline Grains & 0.00 & 0.00 & 0.00 & 0.00 & -0.71 & -0.76 & -27.63 & -19.03 \\
\hline $\begin{array}{l}\text { Vegeta- } \\
\text { blFrut }\end{array}$ & 0.09 & 0.09 & 0.01 & 0.00 & -0.03 & -0.03 & -0.25 & -0.56 \\
\hline Oilseed & 0.00 & 0.00 & 0.00 & 0.00 & 0.00 & 0.00 & -0.23 & 0.26 \\
\hline $\begin{array}{l}\text { Other- } \\
\text { Crops }\end{array}$ & 0.67 & 0.67 & -0.02 & -0.23 & -0.32 & -0.32 & -0.59 & 3.46 \\
\hline Livestock & 0.02 & 0.02 & -0.01 & -0.01 & 0.00 & 0.00 & 0.07 & 0.07 \\
\hline $\begin{array}{l}\text { Forest- } \\
\text { Fisher }\end{array}$ & 0.09 & 0.09 & -0.01 & 0.00 & -0.05 & -0.04 & 0.14 & -0.03 \\
\hline CoalOilGas & 1.47 & 1.48 & -1.11 & -0.74 & -1.17 & -1.14 & 3.64 & 3.68 \\
\hline $\begin{array}{l}\text { FoodMn- } \\
\text { fCS }\end{array}$ & 19.52 & 19.57 & -5.50 & -4.44 & -10.45 & -10.1 & -7.96 & 16.20 \\
\hline $\begin{array}{l}\text { BeverTo- } \\
\text { baco }\end{array}$ & 0.61 & 0.61 & -0.10 & -0.19 & -0.29 & -0.27 & 1.64 & 5.17 \\
\hline $\begin{array}{l}\text { TextileAp- } \\
\text { par }\end{array}$ & 10.51 & 10.53 & -6.17 & -1.40 & -5.81 & -5.55 & 63.63 & 28.16 \\
\hline Leather & 2.87 & 2.87 & -0.68 & -1.11 & -1.36 & -1.33 & 2.50 & 13.45 \\
\hline $\begin{array}{l}\text { WoodPa- } \\
\text { per }\end{array}$ & 8.03 & 8.04 & -1.39 & -1.89 & -6.31 & -6.23 & -1.37 & 8.62 \\
\hline $\begin{array}{l}\text { Petro- } \\
\text { Chemica }\end{array}$ & 128.16 & 128.57 & -33.07 & -3.50 & -117.16 & -115.33 & 43.53 & -5.32 \\
\hline $\begin{array}{l}\text { BasicMet- } \\
\text { als }\end{array}$ & 8.66 & 8.67 & -0.77 & -0.07 & -7.19 & -6.88 & -8.26 & -8.47 \\
\hline $\begin{array}{c}\text { FabMet- } \\
\text { alEqu }\end{array}$ & 34.73 & 34.79 & -9.74 & -5.20 & -29.77 & -27.23 & 42.68 & 36.44 \\
\hline $\begin{array}{l}\text { Motor- } \\
\text { Vehpar }\end{array}$ & 1.21 & 1.21 & -0.02 & -0.53 & -1.08 & -0.55 & -7.18 & 39.9 \\
\hline $\begin{array}{l}\text { OtherM- } \\
\text { nfcs }\end{array}$ & 12.76 & 12.78 & -0.41 & -3.89 & -6.11 & -6.07 & -1.79 & 15.40 \\
\hline Services & -0.07 & -0.05 & -3.05 & -1.35 & -2.76 & -0.53 & 203.78 & 99.40 \\
\hline Total & 229.33 & 229.94 & -62.04 & -24.55 & -190.57 & -182.36 & 306.35 & 236.80 \\
\hline
\end{tabular}

Ethiopia reports large export to non-COMESA region on services, other crops, basic metal, leather, and oilseeds, and textile sector.

\subsubsection{Changes in trade balance and output}

The trade balance effect, which is the relative change in exports and imports, indicates that Ethiopia's trade balance improves more in the scenario 3, and scenario 4 than from the COMESA FTA, which is mainly due to large tariff reduction. For a few sectors, such as other crops, and basic metal, Ethiopia's trade balance improves under scenario 3 and 4 while the reverse is true for vegetables and fruits, and the livestock sector. Moreover, wood paper, food manufacturing, and other manufacturing sectors are exceptional in that their trade balance only improves with the COMESA customs union. Overall, forestry and fishery, grains, oilseeds, and leather are the winning sectors across all scenarios while beverage and tobacco, and textile and apparel losses in all scenarios.

Table 14 further presents the sectoral output effects from liberalization, that is, which sector gains or losses under the four scenarios. Simulation results show that in a few 
Table 13 Changes in Ethiopia's export by destination (US\$ Million). Source: Model Simulation

\begin{tabular}{|c|c|c|c|c|c|c|c|c|}
\hline \multirow[t]{2}{*}{ Sectors } & \multicolumn{4}{|c|}{ Ethiopia export to COMESA } & \multicolumn{4}{|c|}{ Ethiopia export to non-COMESA } \\
\hline & $\begin{array}{l}\text { Scenario } \\
1\end{array}$ & $\begin{array}{l}\text { Scenario } \\
2\end{array}$ & $\begin{array}{l}\text { Scenario } \\
3\end{array}$ & $\begin{array}{l}\text { Scenario } \\
4\end{array}$ & $\begin{array}{l}\text { Scenario } \\
1\end{array}$ & $\begin{array}{l}\text { Scenario } \\
2\end{array}$ & $\begin{array}{l}\text { Scenario } \\
3\end{array}$ & Scenario 4 \\
\hline Grains & 0.10 & 0.11 & -0.28 & -0.21 & 0.09 & 0.17 & 4.54 & 4.04 \\
\hline $\begin{array}{l}\text { Vegeta- } \\
\text { blFrut }\end{array}$ & 7.54 & 7.75 & -17.98 & -5.48 & -0.09 & 0.08 & 9.39 & 8.18 \\
\hline Oilseed & 1.48 & 1.50 & 0.30 & -0.19 & -0.30 & 0.26 & 26.39 & 23.00 \\
\hline $\begin{array}{l}\text { Other- } \\
\text { Crops }\end{array}$ & -1.43 & -1.35 & -1.13 & -1.52 & -0.19 & 1.90 & 98.50 & 88.93 \\
\hline Livestock & 0.78 & 0.90 & -6.24 & -8.01 & -0.01 & 0.03 & 2.65 & 2.39 \\
\hline $\begin{array}{l}\text { Forest- } \\
\text { Fisher }\end{array}$ & 0.17 & 0.17 & 0.03 & 0.00 & 0.01 & -0.09 & 1.45 & 1.56 \\
\hline CoalOilGas & 0.00 & 0.00 & 0.00 & 0.00 & 0.39 & 0.30 & 6.77 & 5.48 \\
\hline $\begin{array}{l}\text { FoodMn- } \\
\text { fCS }\end{array}$ & 3.11 & 3.11 & 0.90 & 0.39 & 0.30 & 0.24 & 10.54 & 9.11 \\
\hline $\begin{array}{l}\text { BeverTo- } \\
\text { baco }\end{array}$ & 0.09 & 0.09 & -0.03 & -0.03 & 0.00 & 0.00 & 0.20 & 0.17 \\
\hline $\begin{array}{l}\text { TextileAp- } \\
\text { par }\end{array}$ & 0.29 & 0.29 & 0.01 & 0.08 & 0.59 & 0.53 & 21.21 & 18.65 \\
\hline Leather & 1.84 & 1.84 & -0.24 & 0.13 & 0.97 & 0.77 & 29.90 & 26.65 \\
\hline $\begin{array}{l}\text { WoodPa- } \\
\text { per }\end{array}$ & 0.50 & 0.50 & -0.08 & -0.12 & 0.03 & 0.03 & 0.42 & 0.37 \\
\hline $\begin{array}{l}\text { Petro- } \\
\text { Chemica }\end{array}$ & 6.47 & 6.46 & 0.11 & 0.73 & 0.31 & 0.28 & 3.53 & 2.42 \\
\hline $\begin{array}{l}\text { BasicMet- } \\
\text { als }\end{array}$ & 0.03 & 0.03 & -0.01 & 0.00 & 1.29 & 1.10 & 29.43 & 24.40 \\
\hline $\begin{array}{c}\text { FabMet- } \\
\text { alEqu }\end{array}$ & 8.43 & 8.39 & -0.52 & 0.73 & 0.24 & 0.16 & 7.62 & 6.74 \\
\hline $\begin{array}{l}\text { Motor- } \\
\text { Vehpar }\end{array}$ & 2.15 & 2.14 & 0.33 & 0.06 & 0.02 & 0.01 & 0.51 & 0.46 \\
\hline $\begin{array}{l}\text { OtherM- } \\
\text { nfcs }\end{array}$ & 1.40 & 1.40 & 0.37 & -0.05 & 0.09 & 0.07 & 2.48 & 2.20 \\
\hline Services & 0.17 & 0.14 & 1.51 & 1.32 & 5.44 & 3.23 & 144.31 & 125.30 \\
\hline Total & 33.12 & 33.47 & -22.95 & -12.17 & 9.18 & 9.07 & 399.84 & 350.05 \\
\hline
\end{tabular}

sectors, such as oilseeds, leather, and basic metals, output increases across all scenarios. In contrast, in certain other sectors, such as vegetables and fruits, livestock, and forestry and fishery, output increases only under the COMESA FTA. Similarly, for food manufacturing, wood paper, and other manufacturing sectors, output increases only under the COMESA customs union.

\section{Conclusion}

The purpose of this study is to provide an in-depth analysis of the impact of the Ethiopia-COMESA FTA, COMESA customs union, and the EPA on the economies of COMESA in general, and in Ethiopia. This study is relevant for policy makers in Ethiopia and COMESA regions to facilitate the existing trade negotiations among member countries by providing an empirical evidence of the impact of tariff reduction. The study uses the standard GTAP model version 9 database. Trade barriers broadly include tariffs and non-tariff barriers. However, this study considers cases where the countries take policy 
Table 14 Changes in Trade balance and output for Ethiopia. Source: Model Simulation

\begin{tabular}{|c|c|c|c|c|c|c|c|c|}
\hline & \multicolumn{4}{|c|}{ Trade balance (US\$ million) } & \multicolumn{4}{|c|}{$\%$ change in output } \\
\hline & $\begin{array}{l}\text { Scenario } \\
1\end{array}$ & $\begin{array}{l}\text { Scenario } \\
2\end{array}$ & $\begin{array}{l}\text { Scenario } \\
3\end{array}$ & $\begin{array}{l}\text { Scenario } \\
4\end{array}$ & $\begin{array}{l}\text { Scenario } \\
1\end{array}$ & $\begin{array}{l}\text { Scenario } \\
2\end{array}$ & $\begin{array}{l}\text { Scenario } \\
3\end{array}$ & Scenario 4 \\
\hline Grains & 0.94 & 1.06 & 33.12 & 23.62 & 0.00 & 0.10 & 0.67 & -0.08 \\
\hline $\begin{array}{l}\text { Vegeta- } \\
\text { blFrut }\end{array}$ & 7.47 & 7.68 & -16.79 & -3.65 & 0.16 & 0.25 & -0.46 & -0.54 \\
\hline Oilseed & 1.23 & 1.68 & 20.51 & 16.91 & 0.25 & 0.39 & 6.24 & 4.83 \\
\hline $\begin{array}{l}\text { Other- } \\
\text { Crops }\end{array}$ & -2.02 & -0.23 & 78.91 & 67.05 & -0.12 & 0.03 & 4.23 & 3.44 \\
\hline Livestock & 0.77 & 0.88 & -7.03 & -8.42 & 0.00 & 0.11 & -0.30 & -0.76 \\
\hline $\begin{array}{l}\text { Forest- } \\
\text { Fisher }\end{array}$ & 0.13 & 0.04 & 0.93 & 1.15 & 0.00 & 0.06 & -0.02 & -0.24 \\
\hline CoalOilGas & 0.03 & -0.09 & 3.43 & 0.94 & -0.08 & -0.08 & 1.60 & 1.34 \\
\hline $\begin{array}{l}\text { FoodMn- } \\
\text { fCs }\end{array}$ & -6.72 & -7.21 & 23.37 & -3.14 & -0.31 & -0.22 & 0.81 & -1.03 \\
\hline $\begin{array}{c}\text { BeverTo- } \\
\text { baco }\end{array}$ & -0.21 & -0.24 & -1.65 & -6.30 & -0.05 & 0.05 & -0.56 & -1.48 \\
\hline $\begin{array}{l}\text { TextileAp- } \\
\text { par }\end{array}$ & -4.14 & -4.51 & -45.15 & -11.16 & -0.32 & -0.22 & -5.78 & -0.67 \\
\hline Leather & 0.76 & 0.55 & 23.53 & 10.22 & 0.03 & 0.09 & 3.56 & 0.98 \\
\hline $\begin{array}{l}\text { WoodPa- } \\
\text { per }\end{array}$ & -1.56 & -1.65 & 3.45 & -4.67 & -0.64 & -0.57 & 1.82 & -1.68 \\
\hline $\begin{array}{l}\text { Petro- } \\
\text { Chemica }\end{array}$ & -6.17 & -8.57 & -0.99 & 20.65 & -0.47 & -0.45 & -0.59 & 1.52 \\
\hline $\begin{array}{l}\text { BasicMet- } \\
\text { als }\end{array}$ & -0.59 & -1.12 & 35.10 & 30.59 & 0.03 & 0.00 & 8.84 & 7.27 \\
\hline $\begin{array}{c}\text { FabMet- } \\
\text { alEqu }\end{array}$ & 2.07 & -0.77 & -30.22 & -22.96 & 0.25 & 0.25 & -0.31 & 0.25 \\
\hline $\begin{array}{l}\text { Motor- } \\
\text { Vehpar }\end{array}$ & 1.98 & 1.40 & 8.36 & -41.37 & 0.70 & 0.71 & 4.50 & -7.30 \\
\hline $\begin{array}{l}\text { OtherM- } \\
\text { nfcs }\end{array}$ & -6.51 & -6.59 & 5.07 & -9.58 & -1.07 & -1.03 & 0.75 & -1.52 \\
\hline Services & 7.01 & 3.12 & -94.21 & -5.41 & 0.00 & 0.06 & 0.02 & 0.01 \\
\hline
\end{tabular}

initiatives to eliminate only their import tariffs. Moreover, this study doesn't consider tax replacement as an experiment to quantify the general equilibrium effects of taxation. Hence, future research focusing on non-tariff measures and tax replacement policy is necessary. The results are interpreted in terms of changes in RGDP, trade, welfare, and industry output. Further, the simulation analysis considers four distinct trade integration scenarios that differ in their level of ambition. It is unlikely that regional trade agreements would result in complete removal of tariffs on all products. As a result, for the customs union (Scenario 3) and EPA (Scenario 4), a list of sensitive products are exempt from trade liberalization while for scenario 1 and 2, we conduct $100 \%$ tariff removal among all COMESA member countries.

Simulation results for scenario 1, that models full FTA among all COMESA regions with standard employment closure, yields negative welfare effect for Ethiopia, Uganda, Zambia, and Zimbabwe, but with unemployment closure (scenario 2), almost all COMESA regions gain in terms of welfare mainly due to endowment effect. An exception to this trend is Zimbabwe, which reports a welfare loss. Scenario 3 (COMESA customs union), shows welfare losses for Ethiopia, Kenya, Madagascar, and Mauritius while 
Egypt, Malawi, Uganda, and Zimbabwe enjoys welfare gain. In contrast, reciprocal tariff removal with EU (scenario 4), result in a positive welfare effect only for Rwanda, Zambia, RSCA, and EU-27 regions. The world, as a whole enjoys welfare gains of US\$154 million, and US $\$ 447$ million with scenario 1 and 2 respectively. Whereas, COMESA customs union and EPA scenarios results in overall welfare losses of around US\$288 million, and US\$47 million respectively. Overall, Rwanda and RSCA emerge as the winner in terms of welfare in all scenarios.

The welfare gains for Ethiopia (US $\$ 22$ million) in scenario 2 are mainly driven by positive allocative efficiency effect and endowment effect. Moreover, there is a large increase in demand for unskilled labor force of around US $\$ 23$ million, US\$112 million, and US $\$ 43$ million for scenario 2, 3, and 4 respectively. While, for other factors of production, we observe an increase in their factor returns across all scenarios. The TOT losses for Ethiopia from scenario 3 and 4 are primarily driven by large drop in export prices for vegetable and fruit, oilseed, other crops, and service sectors.

The simulation results further indicate that the Ethiopian economy reports larger export growth than import for most manufacturing sectors such as wood paper, petroleum chemicals, fabricated metal equipment, and motor vehicle parts with scenario 2 . Moreover, customs union (Scenario 3) and reciprocal tariff removal with EU (Scenario 4) results in large export and import growth for the coal, oil and gas, textiles and apparel, and leather sectors. Overall, forestry and fishery, grains, oilseeds, and leather are the winning sectors, reporting trade surpluses across all scenarios, while beverages and tobacco, textiles and apparel, and fabricated metal equipment are losing sectors, having trade deficits across all scenarios. Simulation result for Ethiopia shows that in a few sectors, such as oilseeds, leather, and basic metals, output increases across all scenarios. In contrast, in certain other sectors, such as vegetables and fruits, livestock, and forestry and fishery, output increases only under the COMESA FTA.

For scenario 1 and 2, Ethiopia reports large exports and imports of food manufacturing, petroleum and chemical, and fabric metal equipment sectors with other COMESA countries. In contrast, with scenario 3 and 4, there is large trade with non-COMESA regions. Therefore, COMESA customs union, and EPA divert trade from COMESA to non-COMESA regions while COMESA FTA increases Ethiopia-COMESA trade. Therefore, there is no strong reason for Ethiopia to move to the customs union, and the EPA in the short run. Therefore, a transition period is necessary, but it is recommended for Ethiopia to join COMESA FTA.

\footnotetext{
Abbreviations

ACP: African Caribbean and Pacific; AGOA: African Growth Opportunity Act; CET: Common external tariff; CFTA: Continental free trade area; CGE: Computable general equilibrium; COMESA: Common Market for Eastern and Southern Africa; EAC: East African Community; EBA: Everything but arms; ECCAS: Economic Community of Central African States; ECOWAS: Economic Community of West African States; EPA: European Partnership Agreement; EU: European Union; EV: Equivalent variation; FTA: Free trade areas; GDP: Gross domestic product; GSP: Generalized system of preferences; GTAP: Global trade analysis project; HS: Harmonized system; MacMap: Market Access Map; MERAGE: Modelling international relationships in applied general equilibrium; MERCOSUR: Mercado Común del Sur; NGO: Non-Governmental Organizations; REA: Rest of East Africa; REC: Regional economic communities; RNA: Rest of North Africa; ROW: Rest of world; RSAC: Rest of South African Customs; RSCA: Rest of South Central Africa; RTA: Regional trade agreements; SADC: Southern African Development Community; SSA: Sub-Saharan Africa; TASTE: Tariff analytical and simulation tool for economists; TFTA: Tripartite free trade area; WITS: World Integrated Trade Solution; WTO: World Trade Organization.
} 
RYOSO Award 2017 from Kobe University for financing our expense at GTAP conference. Earlier version of the paper was presented at the 20th Annual Conference on Global Economic Analysis held on June 7-9, 2017, West Lafayette, Indiana, United States.

Authors' contributions

HSA prepared and designed the research questions, prepare the model experiments, interpret the result, and prepare the manuscripts. TH is a research advisor and he provide intitutive explanation of the model result and prepare the manuscripts. This paper is also part of a Ph.D. thesis of Habtamu Shiferaw, Graduate School of Economics, Kobe University, Japan. Both authors read and approved the final manuscript.

\section{Funding}

We do not have research funding for this paper.

Availability of data and materials

We provide detail summary of our data, its source and version. Further information may be provided upon request. The dataset is available in and bought from the GTAP database version 9.

\section{Competing interests}

The authors declare that they have no competing interests.

\section{Appendices}

\section{Appendices I. Regional aggregation of GTAP 9 Database}

\begin{tabular}{lll}
\hline No & Aggregated region & GTAP regions \\
\hline 1 & Ethiopia & Ethiopia \\
2 & Egypt & Egypt \\
3 & Kenya & Kenya \\
4 & Malawi & Malawi \\
5 & Madagascar & Madagascar \\
6 & Mauritius & Mauritius \\
7 & Rwanda & Rwanda \\
8 & Uganda & Uganda \\
9 & Zambia & Zambia \\
10 & Zimbabwe & Zimbabwe \\
11 & Libya, Algeria, Western Sahara & Rest of North Africa \\
12 & Swaziland, Lesotho & Rest of South African Customs Union \\
13 & Eritrea, Seychelles, Burundi, Comoros, & Rest of Eastern Africa \\
& Djibouti, Sudan, Somalia, Mayotte & \\
14 & D.R. Congo, Angola & South Central Africa \\
15 & European Union & Austria, Belgium, Cyprus, Czech Republic, Denmark, \\
& & Estonia, Finland, France, Germany, Greece, Hungary, \\
& & Ireland, Italy, Latvia, Lithuania, Luxembourg, Malta, \\
& & Netherlands, Poland, Portugal, Slovakia, Slovenia, \\
16 & USA & Spain, Sweden, Bulgaria, Croatia, Romania \\
17 & Rest of Africa & United States \\
18 & ROW & All African regions outside COMESA \\
& & All other regions \\
\hline & & \\
& &
\end{tabular}

(Source) GTAP 9 Database. 


\section{Appendices II. Sectoral aggregation}

\begin{tabular}{llll}
\hline No & New Codes & Sector description & GTAP sectors \\
\hline 1 & Grains & Grains & pdr, wht, gro \\
2 & VegetablFrut & Vegetable and Fruit & v_f \\
3 & Oilseed & Oilseed & osd \\
4 & Othcrops & Other crops & c_b, pfb, ocr \\
5 & Livestock & Livestock & ctl, oap, rmk, wol \\
6 & ForestFisher & Forestry and Fishery & frs, fsh \\
7 & CoalOilGas & Coal, Oil, and Gas & coa, oil, gas, omn \\
8 & FoodMnfcs & Food manufacturing & cmt, omt, vol, mil, pcr, sgr, ofd \\
9 & BeverTobaco & Beverage and Tobacco & b_t \\
10 & TextileAppar & Textile and wearing Apparel & tex, wap \\
11 & Leather & Leather & lea \\
12 & WoodPaper & Wood Paper & lum, ppp \\
13 & PetroChemica & Petroleum and Chemical & p_c, crp, nmm \\
14 & BasicMetals & Basic metals & i_s, nfm \\
15 & FabMetalEqu & Fabric metal Equipment & fmp, otn, ele, ome \\
16 & MotorVehpar & Motor vehicle part & mvh \\
17 & OtherMnfcs & Other manufacturing & omf \\
18 & Services & Services & ely, gdt, wtr, cns, trd, otp, wtp, \\
& & & atp, cmn, ofi, isr, obs, ros, osg, \\
& & dwe \\
\hline
\end{tabular}

(Source) GTAP 9 Data Base.

Received: 1 November 2018 Revised: 5 April 2020 Accepted: 29 December 2020

Published online: 16 January 2021

\section{References}

Aguiar A, Narayanan B, McDougall R (2016) An Overview of the GTAP 9 Data Base. J Global Econ Analy. 1(1):181-208. https://doi.org/10.21642/JGEA.010103AF

Baier SL, Bergstrand JH (2004) Economic determinants of free trade agreements. Journal of International Economics 64(1):29-63. https://doi.org/10.1016/S0022-1996(03)00079-5

Baier SL, Bergstrand JH (2007) Do free trade agreements actually increase members'international trade? Journal of International Economics 71(1):72-95. https://doi.org/10.1016/j.jinteco.2006.02.005

Balassa B (2013) The Theory of Economic Integration (Routledge Revivals). Routledge. https://doi.org/10.4324/97802 03805183

Baldwin, R. (1993). A Domino Theory of Regionalism. NBER Working Paper, 4465(4465). https://doi.org/https://doi. org/10.3386/w4465

Baldwin R, Jaimovich D (2012) Are Free Trade Agreements contagious? Journal of International Economics 88(1):1-16. https://doi.org/10.1016/j.jinteco.2012.03.009

Burfisher, M. E. (2011). Introduction to Computable General Equilibrium Models. Cambridge University Press.

Chen MX, Joshi S (2010) Third-country effects on the formation of free trade agreements. Journal of International Economics 82(2):238-248. https://doi.org/10.1016/j.jinteco.2010.06.003

Conroy, M. (2013). Have Regional Trade Agreements in Developing Countries been a Success or a Failure ? Evidence from the COMESA Free Trade Agreement and MERCOSUR.

Edward J. Balistreri \& Maryla Maliszewska \& Israel Osorio-Rodarte \& David G. Tarr \& Hidemichi Yonezawa, 2016. "Poverty and Shared Prosperity Implications of Reducing Trade Costs Through Deep Integration in Eastern and Southern Africa,"Working Papers 2016-07, Colorado School of Mines, Division of Economics and Business.

Fiorentino, R. V., Crawford, J., \& Toqueboeuf., C. (2009). The Landscape of Regional Trade Agreements and WTO Surveillance. In Multilateralizing Regionalism: Challenges for the Global Trading System, edited by R. Baldwin and P. Low. Cambridge: Cambridge University Press (pp. 28-76). Retrieved from www.cambridge.org/9780521738101

Hamouda, H. Ben, Karingi, S., Ouedraogo, B. I., And, N. O., \& Sadni-Jallab, M. (2006). Assessing the Consequences of the Economic Partnership Agreement on the Ethiopian Economy. African Trade Policy Centre.

Hertel, \& Thomas .W. (1997). Global Trade Analysis: Modelling and Applications. Cambridge University Press.

Jean, S., Laborde, D., \& Martin, W. (2008). Choosing sensitive agricultural products in trade negotiations. ICEPII, Working Paper. 
Karamuriro, H. T. (2015). Regional Economic Integration and Exports Performance in the COMESA Region (1980-2012). International Journal of Business and Economics Research, 4(1), 11-20. https://doi.org/https://doi.org/10.11648/j.ijber .20150401 .12

Karingi, N, S., Siriwardana, M., \& Ronge, E. (2002). Implications of the COMESA Free Trade Area and the Proposed Customs Union : An Empirical Investigation. Presented at the 5th Annual Conference on Global Economic Analysis, Taipei, Taiwan. Purdue University, West Lafayette, IN: Global Trade Analysis Project (GTAP). Retrieved from https://www.gtap.ageco n.purdue.edu/resources/res_display.asp?RecordlD $=994$

Karingi, S. N. and B. F. (2009). Beyond Political Rhetoric - the Meaning of the Grand Eastern and Southern Africa FTA. UN Economic Commission for Africa, (April).

Karingi, S., Oulmane, N., Sadni-Jallab, M., Lang, R., \& Pérez, R. (2006). Assessment of the Impact of the Economic Partnership Agreement between the COMESA countries and the European Union. African Trade Policy Centre.

Krueger AO (1997) Free trade agreements versus customs unions. J Dev Econ 54(1):169-187. https://doi.org/10.1016/ S0304-3878(97)00032-1

Makochekanwa A (2014) Welfare Implications of COMESA - EAC - SADC Tripartite Free Trade Area. African Development Review 26(1):186-202

Mevel, S., \& Karingi, S. (2012). Deepening Regional Integration in Africa: A Computable General Equilibrium Assessment of the Establishment of a Continental Free Trade Area followed by a Continental Customs Union. 7th African Economic Conference Kigali, Rwanda, 30.

Mureverwi, B. (2016). Welfare Decomposition of the Continental Free Trade Area. Presented at the 19th Annual Conference on Global Economic Analysis, Washington DC, USA. Purdue University, West Lafayette, IN: Global Trade Analysis Project (GTAP). Retrieved from https://www.gtap.agecon.purdue.edu/resources/res_display.asp?RecordID=4978

Musila JW (2005) The intensity of trade creation and trade diversion in COMESA, ECCAS and ECOWAS: A comparative analysis. Journal of African Economies 14(1):117-141. https://doi.org/10.1093/jae/ejh039

Narayanan, B., \& Sharma, S. K. (2016). An Analysis of Tariff Reductions in the Trans-Pacific Partnership (TPP): Implications for the Indian Economy. Margin: The Journal of Applied Economic Research, 10(1), 1-34. https://doi.org/https://doi. org/10.1177/0973801015617264

Ngepah N, Udeagha MC (2018) African Regional Trade Agreements and Intra-African Trade. Journal of Economic Integration 33(1):1176-1199

Nzuma, J., Gbegbelegbe, S., Massawe, S., \& Karugia, J. (2009). A Quantitative Assessment of the COMESA Customs Union. ReSAKSS Working Paper. Washington, D.C.: IFPRI, 30.

Persson M (2008) Trade Facilitation and the EU-ACP Economic Partnership Agreements. Journal of Economic Integration 23(3):518-546

Sawkut R, Boopen S (2010) An Assessment of the Impact of a COMESA Customs Union. African Development Review 22(2):331-345

UNCTAD, \& WTO. (2012). A Practical Guide to Trade Policy Analysis.

Vollmer, S., Inmaculada, M.-Z., D, N., Felicitas, \& Nils, K. (2009). EU-ACP Economic Partnership Agreements - Empirical Evidence for Sub-Saharan Africa. In Proceedings of the German Development Economics Conference, Frankfurt a.M (Vol. 39).

\section{Publisher's Note}

Springer Nature remains neutral with regard to jurisdictional claims in published maps and institutional affiliations.

\section{Submit your manuscript to a SpringerOpen ${ }^{\circ}$ journal and benefit from:}

- Convenient online submission

- Rigorous peer review

- Open access: articles freely available online

- High visibility within the field

- Retaining the copyright to your article

Submit your next manuscript at $\boldsymbol{\Delta}$ springeropen.com 